\title{
The effect of different maturity stages on phytochemical composition and antioxidant capacity of cranberry cultivars
}

\author{
Jan Oszmiański $^{1} \cdot$ Sabina Lachowicz ${ }^{1} \cdot$ Józef Gorzelany $^{2} \cdot$ Natalia Matłok $^{2}$
}

Received: 4 August 2017 / Revised: 30 September 2017 / Accepted: 7 October 2017 / Published online: 19 October 2017

(C) The Author(s) 2017. This article is an open access publication

\begin{abstract}
The changes of polyphenols and triterpenoids in three cranberry cultivars ('Pilgrim', 'Stevens', and 'Ben Lear)' from different maturity stages, grown in Poland, were determined using ultra-performance liquid chromatography (UPLC) and photodiode detector-quadrupole/time-of-flight mass spectrometry. Fifty-one bioactive compounds were identified in cranberry fruits, including 48 polyphenols (19 flavonols, 8 anthocyanins, 7 phenolic acids, and 14 flavan3-ol oligomers) and 3 triterpenoids (betulinic, oleanolic, and ursolic acids). The concentrations of individual polyphenolic compounds during ripening were similar, whereas their values differed significantly. Immature fruits showed the lowest level of polyphenolic compounds, which increased in semi-mature cranberry fruits and did not change remarkably in commercially mature cranberry fruits. The quantity of phytochemical compounds during cranberry fruit ripening depended on cultivar, and the cultivar 'Stevens' had significantly higher concentrations of bioactive compounds
\end{abstract}

Sabina Lachowicz

sabina.lachowicz@upwr.edu.pl

Jan Oszmiański

jan.oszmianski@upwr.edu.pl

Józef Gorzelany

gorzelan@ur.edu.pl

Natalia Matłok

nmatlok@ur.edu.pl

1 Department of Fruit, Vegetable and Plant Nutraceutical Technology, Faculty of Biotechnology and Food Science, Wrocław University of Environmental and Life Sciences, 37 Chełmońskiego Street, 51-630 Wrocław, Poland

2 Department of Agro and Food Production Engineering, Faculty of Biology and Agriculture, University of Rzeszów, 4 Zelwerowicza Street, 35-601 Rzeszów, Poland and antioxidant capacity in comparison to the other tested cultivars.

Keywords Cranberry - Sugar - Polyphenolic compounds . Triterpenoids · Antioxidant capacity · UPLC-PDA-MS/ MS

\section{Introduction}

Cranberry fruits have gained interest as rich sources of prohealthy compounds, displaying high nutritive and biological value. They are a good source of vitamins, minerals, organic acids, fiber, and sugars $[1,2]$. The most important groups of phytochemical compounds in cranberry fruit are polyphenolic and triterpene compounds, exhibiting strong antioxidant properties and the ability to alleviate chronic diseases [3-5] and influence their sensory attributes $[1,6$, 7]. During the ripening of plants, there occur series of biochemical reactions which lead to production of these compounds. The differences in content of bioactive compounds depend on many factors such as the cultivar of plant, region of cultivation, soils, and stage of maturity [8].

The polyphenolics are the most widespread group of compounds in nature. They significantly affect the plant during its growth. Depending on the plant growth phase, the content of polyphenols varies. For example, phenolic acid content increases during ripening of tomatoes. In red, ripe strawberries, the phenolic content is higher than in green, immature ones, whereas in the case of apples, the opposite trend is observed $[8,9]$. Polyphenols display mainly antiinflammatory, anti-allergic, antiviral, antifungal, and antihypertensive properties, and minimize the risk of metabolic diseases [10]. Triterpene compounds, on the other hand, are present in the resin, peel and cuticular waxes, and fruit and 
vegetable extracts, acting as protection against the attack of insects and microorganisms. They are widespread in the world of plants and are the subject of numerous phytochemical and pharmacological studies. Plants with high levels of triterpenes are often used in phytotherapy because of their valuable anticancer, antioxidative, anti-inflammatory, antibacterial, antifungal, and antiprotozoal properties [11-13].

There are not enough reports about the influence of different ripening stages on phytochemical concentrations in cranberry fruits. Therefore, the aim of this study was to determine differences in content and amount of basic chemicals and bioactive compounds by UPLC-PDA-MS/MS, and antioxidant capacity (ABTS and FRAP) in the cranberry cultivars 'Ben Lear', 'Stevens', 'Pilgrim'. An additional goal of this study was to compare polyphenolic and triterpenoid compounds in three cultivars, from different maturity stages grown in Poland. Moreover, detailed characterization of triterpenoid and polyphenolic compounds and antioxidant capacity from different maturity stages presented in this paper could be useful for the food processing industry as an important factor in good quality food and for the production of health beneficial products and components in our daily diet.

\section{Materials and methods}

\section{Chemicals}

Acetonitrile, formic acid, betulinic, oleanolic and ursolic acid, ABTS (2,2'-azinobis(3-ethylbenzothiazoline-6-sulfonic acid), 6-hydroxy-2,5,7,8-tetramethylchroman-2-carboxylic acid (Trolox), 2,4,6-tri(2-pyridyl)-s-triazine (TPTZ), methanol, acetic acid, and phloroglucinol were purchased from Sigma-Aldrich (Steinheim, Germany). (-)-Epicatechin, (+)-catechin, chlorogenic acid, neochlorogenic acid, cryptochlorogenic acid, dicaffeic acid, procyanidin A2, procyanidin $\mathrm{B} 2, \mathrm{p}$-coumaric acid, caffeic acid, kaempferol-3-O-galactoside, quercetin-3-O-rutinoside, quercetin-3-O-galactoside, quercetin-3-O-glucoside, cyanidin-3-O-arabinoside, cyanidin-3-O-galactoside cyanidin-3-O-glucoside, peonidin-3-Ogalactoside, and delfinidyn-3-O-glucoside were purchased from Extrasynthese (Lyon, France). Acetonitrile for ultraperformance liquid chromatography (UPLC; Gradient grade) and ascorbic acid were obtained from Merck (Darmstadt, Germany).

\section{Plant material}

Three cranberry (Vaccinium macrocarpon L.) cvs.-—'Ben Lear', 'Pilgrim', and 'Stevens' - from four different maturity stages (1st-immature, IM, 8th-semi-mature, SM, 15th-mature, MM, and 22nd-commercially mature,
CM, of September 2016) were used in this study. Cranberry fruits were obtained from a horticultural farm in Nowiny, commune of Radomyśl nad Sanem, Podkarpackie Region, Poland (N: 50O41'59"-50O42'5" E: 21055'21"-21O55'8"). Soilless culture of cranberry was conducted on a substrate of pure quartz sand, where it was possible to regulate water and fertilizer ratios. The examined cultivars were grown on 1-hectare beds with dykes for flooding with water during harvest and in winter. In 2016, from 24 March to 28 August in the course of 7 procedures, the following fertilizers were applied: Wigor S, triple superphosphate, potassium sulfate, Polimag S, ammonium sulfate, and magnesium sulfate (7-hydrate). In July 2016, Dursban was used as a treatment for May bug larvae, in the amount of $2.5 \mathrm{~kg} / \mathrm{ha}$. In each cultivar, samples of $1 \mathrm{~kg}$ were collected manually, using an identical method. Harvesting time was 8-20 September. The total amount of fertilizers administered to the plants in 2016 was: sodium (Na) $75.5 \mathrm{~kg}$, phosphorus (P) $132 \mathrm{~kg}$, potassium (K) $185 \mathrm{~kg}$, magnesium $(\mathrm{Mg}) 52.5 \mathrm{~kg}$, and sulfur (S) $512.85 \mathrm{~kg}$ per 1 hectare of land. Mean annual temperature and annual total precipitation were $11.4{ }^{\circ} \mathrm{C}$ and $350.00 \mathrm{~mm}$ during 2016 at the plantation of Radomyśl nad Sanem.

The raw material was collected at four different maturity stages. Next, the samples were frozen and dried using an Alpha 1-4 LSC freeze dryer (Christ, Osterode, Germany). The homogeneous dry material was obtained by crushing the dried tissues using a closed laboratory mill (IKA A.11, Germany). The powders were kept in a refrigerator $\left(-80^{\circ} \mathrm{C}\right)$ until extract preparation.

\section{Physicochemical analyses}

Dry matter content was determined by a moisture analyzer (MB 25, Ohaus, USA). Approximately $3 \mathrm{~g}$ of sweet cherry homogenate was dried at $105{ }^{\circ} \mathrm{C}$ [14]. Titratable acidity (TA) was determined by titration aliquots of homogenate of fresh fruits by $0.1 \mathrm{~N} \mathrm{NaOH}$ to an end point of $\mathrm{pH} 8.1$ using an automatic $\mathrm{pH}$ titration system (pH-meter type IQ 150; Warsav, Polska) and expressed as g of malic acid. The $\mathrm{pH}$ was measured with the same equipment used for TA, while the soluble solid content (SSC) was determined in fresh juices by refractometer (AtagoRx 5000, Atago Co. Ltd., Japan) and expressed as Brix. Pectins content was analyzed according to the Morris method [15] and expressed as $\mathrm{g} / 100 \mathrm{~g}$. Results are reported as the arithmetic mean of three independent repetitions $(n=2)$, taking into account the standard deviation (SD).

\section{Extraction procedure}

The powder samples of fruits $(1 \mathrm{~g})$ were extracted with $10 \mathrm{~mL}$ of mixture containing HPLC-grade methanol $(30 \mathrm{~mL} / 100 \mathrm{~mL})$, ascorbic acid $(1.0 \mathrm{~g} / 100 \mathrm{~mL})$, and acetic 
acid in $1.0 \mathrm{~mL} / 100 \mathrm{~mL}$ of reagent. The extraction was performed twice by incubation for 20 min under sonication 20 $\min , 20^{\circ} \mathrm{C}, 40 \mathrm{kHz}$ (Sonic 6D, Polsonic, Warsaw, Poland) and with occasional shaking. Next, the slurry was centrifuged at $19,000 \mathrm{~g}$ for $10 \mathrm{~min}$, and the supernatant was filtered through a Hydrophilic PTFE $0.20 \mu \mathrm{m}$ membrane (Millex Samplicity Filter, Merck, Darmstadt, Germany) and used for analysis. The content of polyphenols in individual extracts was determined by means of the ultra-performance liquid chromatography-photodiode array detector-mass spectrometry method [16]. All extractions were carried out in triplicate.

\section{Identification and quantification of polyphenols}

Qualitative (LC-Q-TOF-MS) and quantitative (UPLC-PDA-FL) analyses of polyphenols (anthocyanins, flavan-3-ols, flavonols, and phenolic acids) were performed as described previously by Lachowicz et al. [16]. Separations of individual polyphenols were carried out using a UPLC BEH C18 column $(1.7 \mu \mathrm{m}, 2.1 \times 100 \mathrm{~mm}$, Waters Corporation, Milford, MA) at $30{ }^{\circ} \mathrm{C}$. The samples $(10 \mu \mathrm{L})$ were injected, and the elution was completed in $15 \mathrm{~min}$ with a sequence of linear gradients and isocratic flow rates of $0.45 \mathrm{~mL} / \mathrm{min}$. The mobile phase consisted of solvent A (2.0\% formic acid, v/v) and solvent B (100\% acetonitrile). The program began with isocratic elution with $99 \%$ solvent $\mathrm{A}(0-1 \mathrm{~min})$, and then, a linear gradient was used until $12 \mathrm{~min}$, lowering solvent A to $0 \%$; from 12.5 to $13.5 \mathrm{~min}$, the gradient returned to the initial composition (99\% A), and then, it was held constant to re-equilibrate the column. All measurements were repeated three times. The results were expressed as $\mathrm{mg}$ per $100 \mathrm{~g}$ of dry matter $(\mathrm{dm})$.

\section{Analysis of proanthocyanidins by phloroglucinolysis}

Direct phloroglucinolysis of freeze-dried samples was performed as described by Lachowicz et al. [17]. Fruit and pomace lyophilisates were weighed in an amount of $5 \mathrm{mg}$ into 2-mL Eppendorf vials. Subsequently, $0.8 \mathrm{~mL}$ of the methanolic solution of phloroglucinol $(75 \mathrm{~g} / \mathrm{L})$ and ascorbic acid $(15 \mathrm{~g} / \mathrm{L})$ were added to samples. After addition of $0.4 \mathrm{~mL}$ of methanolic $\mathrm{HCl}(0.3 \mathrm{M})$, the vials were incubated for $30 \mathrm{~min}$ at $50{ }^{\circ} \mathrm{C}$ with continuous vortexing in a thermo shaker (TS100, BioSan, Riga, Latvia). The reaction was terminated by placing the vials in an ice bath, drawing $0.6 \mathrm{~mL}$ of the reaction medium and diluting with $1.0 \mathrm{~mL}$ of sodium acetate buffer $(0.2 \mathrm{M})$. The samples were centrifuged immediately at $20,000 \mathrm{~g}$ for $10 \mathrm{~min}$ at $4{ }^{\circ} \mathrm{C}$ and stored at $4{ }^{\circ} \mathrm{C}$ before reverse-phase HPLC (RP-HPLC) analysis. All incubations were done in triplicate. Phloroglucinolysis products were separated on a Cadenza CD C18 $(75 \mathrm{~mm} \times 4.6 \mathrm{~mm}, 3 \mu \mathrm{m})$ column (Imtakt, Japan). The liquid chromatograph was a
Waters (Milford, MA) system equipped with diode array and scanning fluorescence detectors (Waters 474) and an autosampler (Waters 717 plus). Solvent A ( $25 \mathrm{~mL}$ aqueous acetic acid and $975 \mathrm{~mL}$ water) and solvent B (acetonitrile) were used in the following gradients: initial, $5 \% \mathrm{~B} ; 0-15 \mathrm{~min}$ to $10 \%$ B linear; $15-25$ min to $60 \%$ B linear; followed by washing and reconditioning of the column. Other parameters were as follows: a flow rate of $1 \mathrm{~mL} / \mathrm{min}$, an oven temperature of $15{ }^{\circ} \mathrm{C}$, and volume of filtrate injected onto the HPLC system was $20 \mu \mathrm{L}$. All data were obtained in triplicate. The results were expressed as $\mathrm{mg}$ per $100 \mathrm{~g} \mathrm{dm}$.

\section{Identification and quantification of triterpenoids}

Fruit sample extraction was performed as described by Farneti et al. [18]. The powder samples $(0.5 \mathrm{~g})$ were extracted with $5 \mathrm{~mL}$ of ethyl acetate and $5 \mathrm{~mL}$ of hexane. The extraction was performed by incubation for $20 \mathrm{~min}, 20^{\circ} \mathrm{C}, 40 \mathrm{kHz}$ under sonication (Sonic 6D, Polsonic, Warsaw, Poland) with occasional shaking. After the first extraction, the samples were kept at $4{ }^{\circ} \mathrm{C}$ overnight. On the next day, the samples were re-extracted in the same conditions. Next, the slurry was centrifuged at $19,000 \mathrm{~g}$ for $10 \mathrm{~min}$, and the supernatant was evaporated to dryness. The pellet was re-extracted using $2 \mathrm{~mL}$ of $100 \%$ methanol, filtered through a hydrophilic PTFE $0.20 \mu \mathrm{m}$ membrane (Millex Simplicity Filter, Merck, Darmstadt, Germany), and used for analysis. Identification and quantification of ursolic, oleanolic, and betulinic acids were done using the ACQUITY Ultra-Performance LC system with a binary solvent manager (Waters Corp., Milford, MA, USA), a UPLC BEH C18 column $(1.7 \mu \mathrm{m}$, $2.1 \mathrm{~mm} \times 150 \mathrm{~mm}$, Waters Corp., Milford, MA, USA), and a Q-TOF mass spectrometer (Waters, Manchester, UK) equipped with an electrospray ionization (ESI) source, operating in negative mode. The elution solvents were $100 \%$ methanol (A) and 100\% acetonitrile (B) (15:85, v/v). Ursolic, oleanolic, and betulinic acids were eluted isocratically at a flow rate of $0.1 \mathrm{~mL} / \mathrm{min}$ for $10 \mathrm{~min}$ at $20^{\circ} \mathrm{C}$. The $\mathrm{m} / \mathrm{z}$ for betulinic acid was 455.34 , for oleanolic acid 455.34 , and for ursolic acid 455.33, and the retention times were 6.80, 7.50, and $8.85 \mathrm{~min}$, respectively. The compounds were monitored at $210 \mathrm{~nm}$. All data were obtained in triplicate. The results were expressed as mg per $\mathrm{kg}$ of $\mathrm{dm}$.

\section{Analysis of sugar by the HPLC-ELSD method}

An analysis of sugar by the HPLC-ELSD method was performed according to the protocol described by Oszmiański and Lachowicz [10]. Calibration curves $\left(R^{2}=0.9999\right)$ were created for glucose, fructose, sorbitol, and sucrose. All data were obtained in triplicate. The results were expressed as mg per $100 \mathrm{~g} \mathrm{dm}$. 


\section{Determination of antioxidant activity}

The samples for analysis were prepared as described previously by Lachowicz et al. [16]. Freeze-dried fruits $(0.5 \mathrm{~g})$ were mixed with $10 \mathrm{~mL}$ of $\mathrm{MeOH} /$ water $(80: 20 \%$, v/v) $+1 \%$ $\mathrm{HCl}$, sonicated at $20^{\circ} \mathrm{C}$ for $15 \mathrm{~min}$, and left for $24 \mathrm{~h}$ at $4{ }^{\circ} \mathrm{C}$. Then, the extract was again sonicated for $15 \mathrm{~min}$ and centrifuged at $15,000 \mathrm{~g}$ for $10 \mathrm{~min}$.

The ABTS radical cation and ferric reducing antioxidant power (FRAP) methods were also used as described by Re et al. [19] and Benzie and Strain [20], respectively. Briefly, $10 \mu \mathrm{L}$ of the supernatant was mixed with $990 \mu \mathrm{L}$ of ABTS or FRAP. After 6 and 10 min of reaction, the absorbance was measured at $734 \mathrm{~nm}$ for ABTS and $593 \mathrm{~nm}$ for FRAP, respectively. Determinations by the ABTS and FRAP methods were performed using the UV-2401 PC spectrophotometer (Shimadzu, Kyoto, Japan). The antioxidant activity was expressed as mmol of Trolox per $100 \mathrm{~g}$ of $\mathrm{dm}$.

\section{Statistical analysis}

Statistical analysis, one-way ANOVA, and principal component analysis (PCA) were conducted using Statistica version 12.5 (StatSoft, Kraków, Poland). Significant differences $(p \leq 0.05)$ between mean values were evaluated by one-way ANOVA and Duncan's multiple range test. Pearson's correlations were determined using Microsoft Excel 2010.

\section{Results and discussion}

\section{Basic chemical composition}

The analytical results of cranberry fruits for dry weight, total carotenoids, pectins, titratable acidity, $\mathrm{pH}$, and sugars of the three cranberry cultivars are given in Table 1 . Significant differences $(p<0.05)$ were revealed for the investigated basic chemical parameters among all cultivars grown in Poland.

The average content of dry matter in the cranberry fruits was $13.0 \mathrm{~g} / 100 \mathrm{~g}$ in cv. 'Pilgrim' and was 0.8 and $5.4 \%$ lower in cvs. 'Stevens' and 'Ben Lear', respectively. These results were comparable to those obtained in fruits of the cranberry cultivars grown in Poland [21]. The average amount of total carotenoids varied from 0.3 in cv. 'Stevens' to $0.4 \mathrm{~g} / 100 \mathrm{~g}$ for cvs. 'Ben Lear' and 'Pilgrim'. The average value of $\mathrm{pH}$ of cranberry fruits of analyzed cultivars ranged from 2.8 in cvs. 'Stevens' and 'Pilgrim' to 3.0 for cv. 'Ben Lear', respectively. Titratable acidity and the ratio of sugar (soluble solids) to acid contents are two important determinants of fruit taste and consumer's acceptability. The average content of total titratable acidity in different cultivars, expressed as $\mathrm{g} / 100 \mathrm{~g}$ of citric acid, varied from 2.2 to $2.3 \mathrm{~g} / 100 \mathrm{~g}$ for cvs.

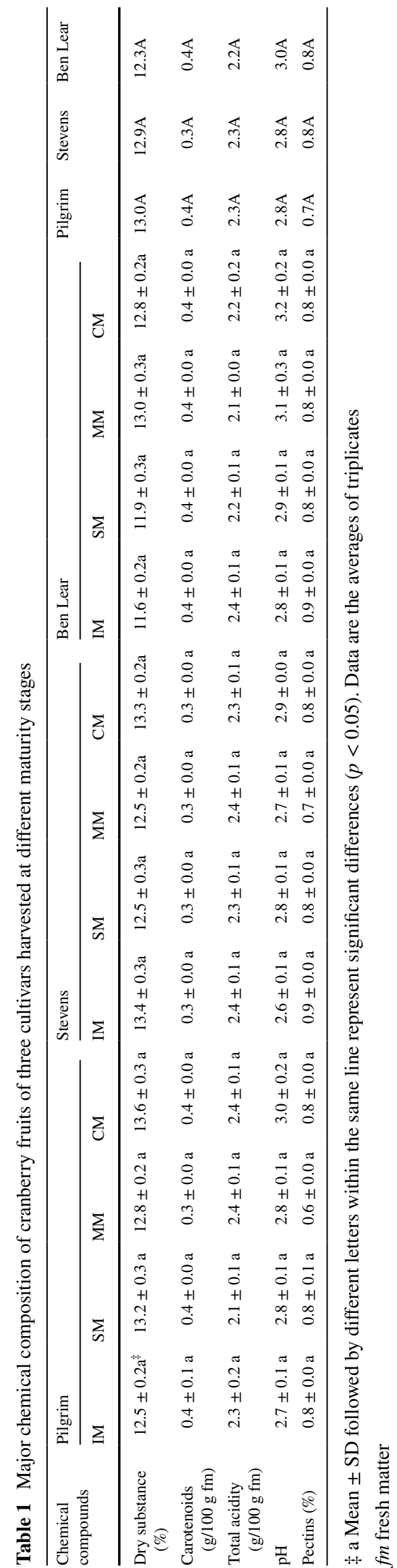


'Ben Lear' and 'Stevens' and 'Pilgrim', respectively. The results of the acidity content and $\mathrm{pH}$ of cranberry varieties tested were comparable with those of Oszmiański et al. [21], Úwieczkowska et al. [22] and Shin et al. [23]. Pectin is one form of soluble fiber responsible for the prevention of diabetes, obesity, and cardiovascular disease [24, 25]. The average pectin value in cranberry fruits of the tested cultivars ranged from 0.7 to $0.8 \%$ for cvs. 'Pilgrim' and 'Stevens' and 'Ben Lear'.

Glucose, fructose, and sucrose were the main sugars analyzed in all the cultivars of cranberry fruits (Fig. 1). According to the literature data [26] in cranberry and raspberry, the main sugar were also fructose, glucose, and sucrose, and their amount varied based on the phases of ripeness. The average amount of total sugar in cranberry cultivars harvested in different maturity stages grown in Poland was $4.57 \mathrm{~g} / 100 \mathrm{~g}$ in cv. 'Ben Lear', and it was 5.7 and 13.1\% higher than cvs. 'Pilgrim' and 'Stevens', respectively. The concentration of total sugar increased remarkably in fruit cvs. 'Pilgrim', 'Stevens', and 'Ben Lear' ripening (38.4, 34.9 , and $40.9 \%$, respectively), from immature to the commercially mature stage. According to research by Ferreyra et al. [27], the total concentration of sugars increased along all the ripening different maturity stages in the strawberry cultivar 'Selva'. Furthermore, during fruit ripening, the content of sugars in cv. 'Pilgrim' increased from phase immature to semi-mature by around $11.1 \%$, from phase semi-mature mature by around $14.4 \%$ and from phase mature to commercially mature by around $19.0 \%$; in cv. 'Stevens'-19.5, 11.1, and 9.0\%, respectively, and in cv. 'Ben Lear'-24.5, 21.2, and 0.5\%, respectively. The major sugar identified in cranberry fruits of analyzed cultivars was fructose (range from 58.9 to $68.7 \%$ of total sugar) followed by glucose (range from 29.6 to $39.3 \%$ ) and sucrose (range from 1.7 to $1.9 \%$ ). Researched fruits of cranberry, raspberry, and strawberry contained higher fructose and glucose and lower sucrose. The low amount of sucrose in the fruits may result from enzymatic hydrolysis from the leaves after their translocation. Furthermore, fructose is sweeter than sucrose or glucose, and its concentration is a desirable sensory trait $[21,26,27]$.

\section{Identification and quantification of phenolic compounds in cranberry}

Identification and quantification of 48 compounds belonging to anthocyanins, phenolic acids, flavonols, and flavan3-ols were based on a comparison of their retention times (Rt) and MS and MS/MS data with available standards and published data. The identification and concentration phenolic results are presented in Table 2. Structures of these compounds were identified by comparison of their spectral and MS and/or MS/MS data to those reported in previous studies [21, 28-31].

The concentration of the polyphenolics in cranberry fruit determination in cultivars ('Pilgrim', 'Stevens' and 'Ben Lear') grown in Poland is presented in Table 3 and Fig. 2. Total concentration of polyphenolic compounds in fruits depends on, among other things, cultivar (Wang et al. [26]). The main classes of polyphenols in the analyzed cranberry cultivars were: flavan-3-ols (from 41.5 to $52.2 \%$ ) > flavonols (from 18.6 to $30.5 \%$ ) > anthocyanins

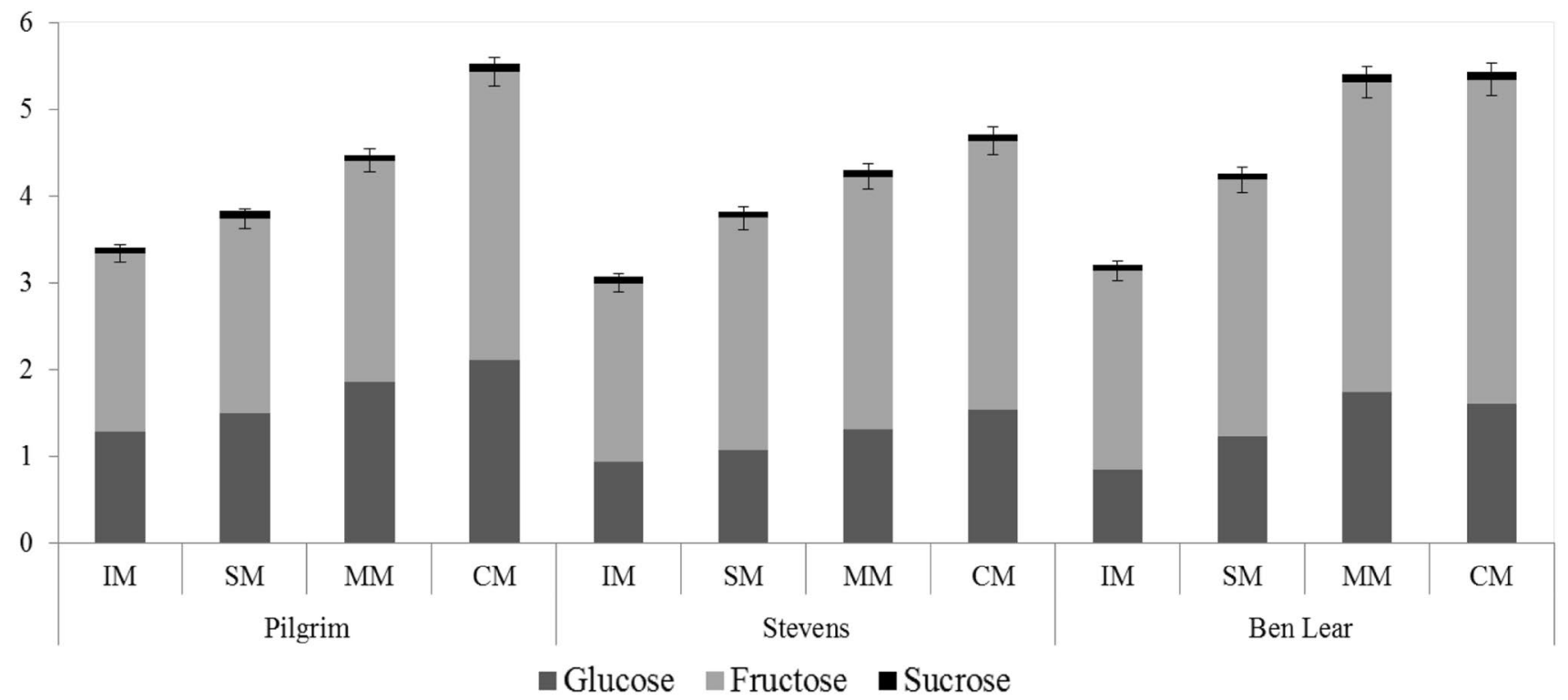

Fig. 1 Content of sugar $(\mathrm{g} / 100 \mathrm{~g})$ (values are mean \pm standard deviation, $n=3$ ) of cranberry fruits of three cultivars harvested at different maturity stages. $I M$ immature, $S M$ semi-mature, $M M$ mature, $C M$ commercially mature 
Table 2 Identification of cranberry fruits of three cultivars harvested at different maturity stages

\begin{tabular}{|c|c|c|c|c|c|}
\hline No. & Tentative identification $^{\mathrm{a}}$ & $\mathrm{Rt}(\min )$ & $\lambda_{\max }(\mathrm{nm})$ & $\begin{array}{l}\mathrm{MS}[\mathrm{H}-\mathrm{M}]^{-/} \\
{[\mathrm{H}-\mathrm{M}]^{+}}\end{array}$ & $\begin{array}{l}\text { MS/MS frag- } \\
\text { ments }(m / z)\end{array}$ \\
\hline 1 & $p$-Coumaroyl-hexose & 3.38 & 310 & 325 & 163 \\
\hline 2 & Caffeoyl dihexoside & 3.64 & 320 & 503 & $341 / 179$ \\
\hline 3 & Delfinidyn-3-O-glucoside ${ }^{\mathrm{b}}$ & 3.65 & 520 & $464^{+}$ & 303 \\
\hline 4 & A-type PA-tetramer & 3.72 & 280 & 1151 & 289 \\
\hline 5 & B-type PA-dimer ${ }^{b}$ & 3.88 & 280 & 577 & 289 \\
\hline 6 & Caffeoyl hexoside & 3.96 & 320 & 341 & 179 \\
\hline 7 & Caffeoyl hexoside isomer & 4.15 & 320 & 341 & 179 \\
\hline 8 & Cyanidin-3-O-galactoside ${ }^{\mathrm{b}}$ & 4.17 & 515 & $449^{+}$ & 287 \\
\hline 9 & Chlorogenic acid ${ }^{\mathrm{b}}$ & 4.28 & 320 & 353 & $191 / 146$ \\
\hline 10 & $(+)$-catechin ${ }^{\mathrm{b}}$ & 4.30 & 280 & 289 & $245 / 203$ \\
\hline 11 & Cyanidin-3-O-glucoside ${ }^{\mathrm{b}}$ & 4.42 & 515 & $449^{+}$ & 287 \\
\hline 12 & $p$-Coumaroyl-hexose isomer & 4.47 & 310 & 325 & 163 \\
\hline 13 & Cyanidin-3- $O$-arabinoside ${ }^{\mathrm{b}}$ & 4.67 & 515 & $419^{+}$ & 287 \\
\hline 14 & $p$-Coumaroyl-hexose isomer & 4.81 & 310 & 325 & 163 \\
\hline 15 & B-type PA-dimer ${ }^{b}$ & 4.92 & 280 & 577 & 289 \\
\hline 16 & Peonidin-3-O-galactoside ${ }^{\mathrm{b}}$ & 4.98 & 515 & $463^{+}$ & 301 \\
\hline 17 & Sinapyl-hexose & 5.07 & 320 & 385 & 223 \\
\hline 18 & Peonidin-3-O-glucoside & 5.26 & 515 & $463^{+}$ & 301 \\
\hline 19 & (-)-Epicatechin ${ }^{\mathrm{b}}$ & 5.30 & 280 & 289 & $245 / 203$ \\
\hline 20 & Peonidin-3- $O$ - arabinoside & 5.48 & 515 & $433^{+}$ & 301 \\
\hline 21 & A-type PA-trimer & 5.61 & 280 & 863 & 289 \\
\hline 22 & Malvidin-3-O-arabinoside & 5.80 & 520 & $463^{+}$ & 331 \\
\hline 23 & A-type PA-tetramer & 5.89 & 280 & 1151 & 289 \\
\hline 24 & Myricetin-3-O-galactoside ${ }^{\mathrm{b}}$ & 6.10 & 355 & 479 & 317 \\
\hline 25 & Myricetin-3-O-glucoside & 6.21 & 355 & 479 & 317 \\
\hline 26 & A-type PA-trimer & 6.31 & 280 & 863 & 289 \\
\hline 27 & Myricetin-3-O-pentoside & 6.41 & 355 & 449 & 317 \\
\hline 28 & A-type PA-dimer ${ }^{b}$ & 6.54 & 280 & 575 & 289 \\
\hline 29 & Myricetin-3-O-pentoside & 6.73 & 355 & 449 & 317 \\
\hline 30 & Myricetin-3-O-pentoside & 6.84 & 355 & 449 & 317 \\
\hline 31 & Quercetin-3-O-galactoside ${ }^{\mathrm{b}}$ & 7.00 & 355 & 463 & 301 \\
\hline 32 & Myricetin-3-O-glucuronide & 7.11 & 355 & 493 & 317 \\
\hline 33 & B-type PA-dimer & 7.14 & 280 & 577 & 289 \\
\hline 34 & A-type PA-dimer & 7.31 & 280 & 575 & 289 \\
\hline 35 & Quercetin-3- $O$-pentoside & 7.44 & 350 & 433 & 301 \\
\hline 36 & Quercetin-3- $O$-pentoside & 7.61 & 350 & 433 & 301 \\
\hline 37 & A-type PA-tetramer & 7.61 & 280 & 1151 & 289 \\
\hline 38 & A-type PA-trimer & 7.71 & 280 & 863 & 289 \\
\hline 39 & Quercetin-3-O-pentoside & 7.79 & 350 & 433 & 301 \\
\hline 40 & Methoxyquercetin-hexoside & 7.93 & 350 & 477 & 315 \\
\hline 41 & Methoxyquercetin-pentoside & 8.03 & 350 & 447 & 315 \\
\hline 42 & Quercetin-3-O-glucoside ${ }^{\mathrm{b}}$ & 8.06 & 355 & 463 & 301 \\
\hline 43 & Quercetin-p-coumaroyl-hexoside & 8.47 & 313 & 609 & $463 / 301$ \\
\hline 44 & Quercetin-3- $O$-rhamnoside & 8.70 & 350 & 447 & 301 \\
\hline 45 & Phloridzin & 8.94 & 280 & 435 & 285 \\
\hline 46 & Methoxyquercetin-pentoside & 8.95 & 350 & 447 & 315 \\
\hline 47 & Methoxyquercetin-hexoside & 9.10 & 350 & 477 & 315 \\
\hline 48 & Quercetin- $p$-coumaroyl-hexoside & 9.75 & 313 & 609 & $463 / 301$ \\
\hline
\end{tabular}

${ }^{a}$ Identification by comparison of MS data with the literature and their identification is tentative

${ }^{\mathrm{b}}$ Identification confirmed by commercial standards 
(from 8.0 to $24.4 \%$ ) > phenolic acids (from 5.0 to $12.1 \%$ ). No differences in the tested cranberry cultivars in the amount of polyphenols and slight differences in the amount of polyphenols were found among examined cultivars during ripening. The average concentration of the polyphenolics in cranberry cultivars from different maturity stages ranged from $3601.9 \mathrm{mg} / 100 \mathrm{~g} \mathrm{dm}$ in cv. 'Ben Lear' to $4142.1 \mathrm{mg} / 100 \mathrm{~g} \mathrm{dm}$ in $\mathrm{cv}$. 'Stevens'. According to Oszmiański et al. [28], the content of polyphenolic compounds in cranberry cvs. 'Pilgrim', 'Stevens', and 'Ben Lear' was 2.0, 2.5, and 3.0 times higher than the same cultivars in this study in the commercially mature phase. The phenolic compounds in cranberry fruits depend on many factors, such as environmental factors, climatic conditions during growth, place of growth, and agricultural practices [27].

\section{Flavan-3-ols}

The average content of the flavan-3-ols in cranberry cultivars harvested in different maturity sages ranged from 1733.1 in cv. 'Ben Lear' to $1958.1 \mathrm{mg} / 100 \mathrm{~g} \mathrm{dm}$ in cv. 'Pilgrim' (Table 3 and Fig. 2). According to Oszmiański et al. [28], the amounts of polyphenolic compounds in cranberry cvs. 'Stevens', 'Pilgrim', and 'Ben Lear' were 1.2, 1.1, and 1.3 times lower than the same cultivars, in this study, in the commercially mature phase. The concentrations of polymer procyanidins (the major group of flavan-3-ols) were heterogeneous and depended on maturity of fruits, and they declined remarkably during fruit cv. 'Pilgrim', 'Stevens', and 'Ben Lear' ripening, by around 9.4, 15.2, and $19.0 \%$, respectively, from the immature stage to the commercially mature stage. Similar results were obtained by Oszmiański et al. [28] for cranberry cultivars 'Pilgrim', 'Ben Lear', and 'Stevens'. In addition, the content of flavan-3-ol monomers $[(+)$ catechin and (-)epicatechin] increased slightly during ripening from the immature stage to the commercially mature stage in cv. 'Pilgrim' (25\%), and decreased in cvs. 'Stevens' and 'Bel Lear' (2.0 and $36.8 \%$, respectively).

\section{Flavonols}

The average concentration of flavonols in the cranberry cultivars analyzed at different maturity stages was $1201.6 \mathrm{mg} / 100 \mathrm{~g} \mathrm{dm}$ in cv. 'Pilgrim' and was 36.1 and $18.7 \%$ higher than cvs. 'Ben Lear' and 'Stevens', respectively (Table 3 and Fig. 2). According to Oszmiański et al. [28], the concentration of flavonol compounds in cranberry cvs. 'Pilgrim', 'Stevens', and 'Ben Lear' were 3.0, 3.2, and 2.9 times higher than the same cultivars in this study in the commercially mature phase. The content of flavonols in cranberry cultivars harvested at different maturity stages increased by 25,9 , and $1 \%$ in cvs. 'Pilgrim' 'Stevens', and 'Ben Lear', respectively, from the immature stage to the commercially mature stage. Similar results were obtained by Ferreyra et al. [27] for strawberry. The major flavonol compounds in cranberry fruits of analyzed cultivars were quercetin-3-O-galactoside (from 31.3 to $38.4 \%$ of total flavonols), myricetin-3-O-galactoside (from 20.4 to $29.0 \%$ ), and quercetin-3-O-pentoside (from 10.1 to $11.8 \%$ ). Similar results were obtained by Oszmiański et al. [21] and White et al. [32].

\section{Anthocyanins}

The average content of anthocyanins in three cranberry cultivars harvested at different maturity stages was $690.4 \mathrm{mg} / 100 \mathrm{~g} \mathrm{dm}$ in cv. 'Ben Lear' and it was 50.6 and 6.0\% higher than cvs. 'Pilgrim' and 'Stevens', respectively (Table 3 and Fig. 2). According to Oszmiański et al. [21], the content of polyphenolic compounds in cranberry cvs. 'Pilgrim', 'Stevens', and 'Ben Lear' was $2.3,1.9$, and 2.4 times higher than the same cultivars in this study in the commercially mature phase. It was suggested that the concentration of anthocyanins in cranberry fruits depends mainly on cultivar, growing place, environmental, climatic, and genetic factors [16]. The composition of anthocyanins increased remarkably in fruit cvs. 'Pilgrim', 'Stevens', and 'Ben Lear' during ripening (57.3, 47.0, and $30.0 \%$, respectively), from the immature to the commercially mature stage. Furthermore, during fruit ripening, the content of anthocyanins in cv. 'Pilgrim' increased from the immature to the semi-mature phase by around $17.0 \%$, from the semi-mature mature phase by around $6.0 \%$ and from the mature to commercially mature phase by around $26.3 \%$; in cv. 'Stevens' - 21.0, 21.0, and $25.0 \%$, respectively, and in cv. 'Ben Lear'-52.7, 20.7, and $20.0 \%$, respectively. Similar results were reported by Ferreyra et al. [27] for strawberry. In addition, the major anthocyanin compounds in cranberry fruits of analyzed cultivars were cyanidin-3-O-galactoside (from 32.6 to $45.0 \%$ of total anthocyanins) and peonidin-3-O-galactoside (from 22.7 to $32.2 \%$ ). According to Oszmiański et al. [28], cyanidin-3-O-galactoside and peonidin-3-Ogalactoside were also major compounds $(23.3-30.0 \%$ and $33.1-39.3 \%$ ) of all the anthocyanins in cranberry cultivars. The anthocyanin composition in cranberry fruits depends on the climate, cultivar, growing location, genetic traits, and environmental factors [27].

\section{Phenolic acids}

The average concentration of phenolic acids in analyzed cranberry cultivars harvested at different maturity stages ranged from $236.8 \mathrm{in} \mathrm{cv}$. 'Ben Lear' to $351.5 \mathrm{mg} / 100 \mathrm{~g} \mathrm{dm}$ in cv. 'Pilgrim' (Table 3 and Fig. 2). According to Oszmiański 


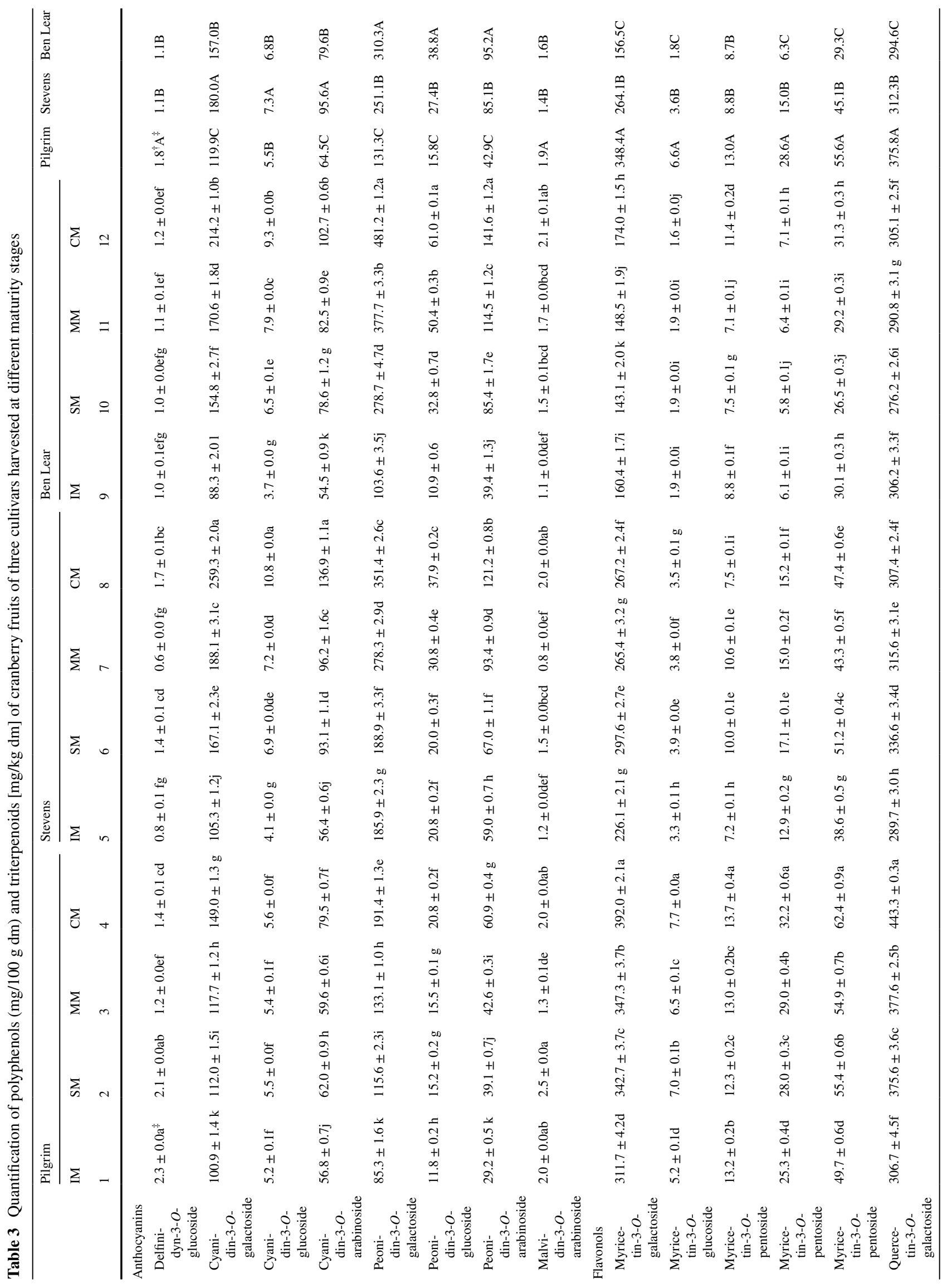




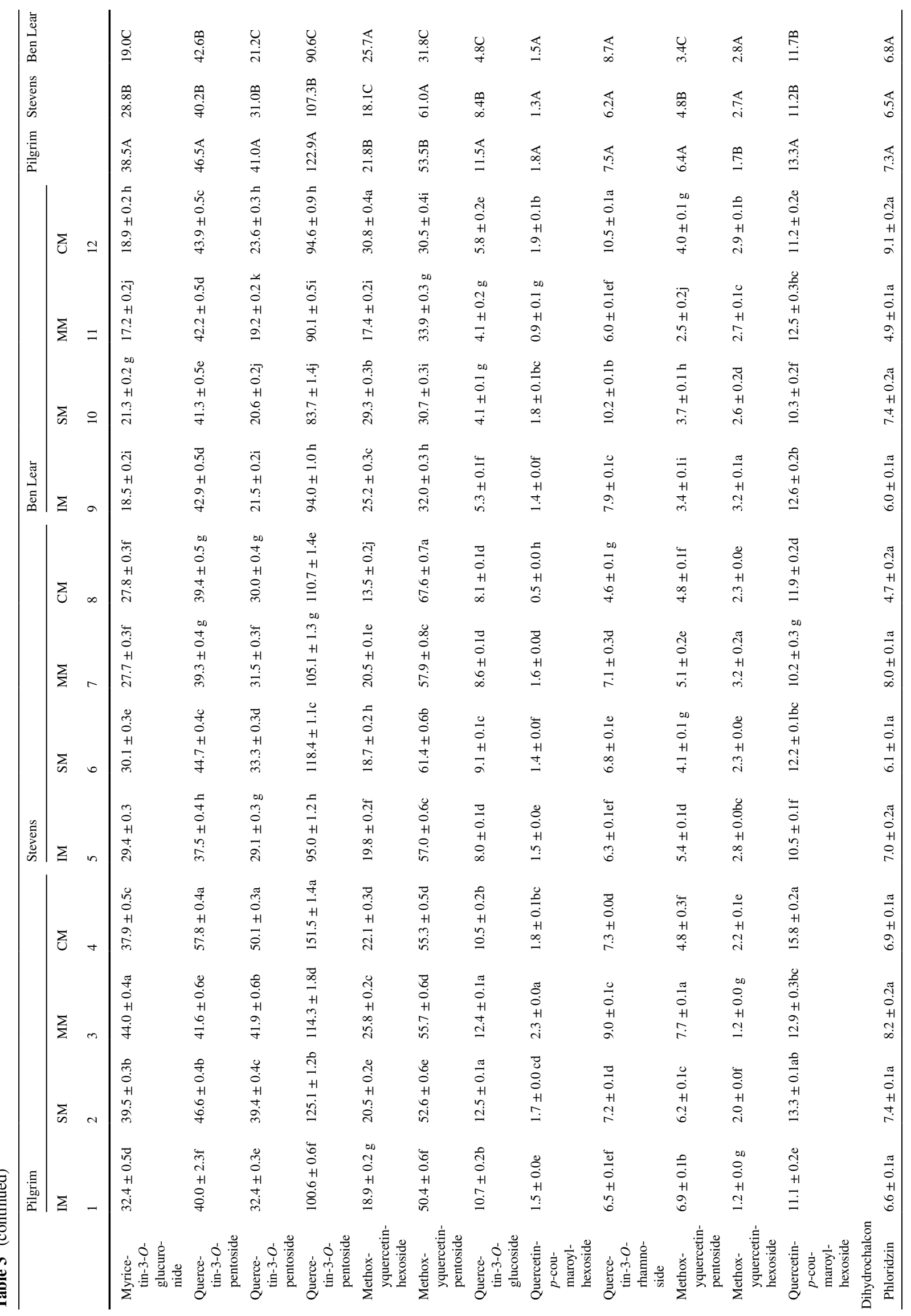




\begin{tabular}{|c|c|c|c|c|c|c|c|c|c|c|c|c|c|c|c|c|c|c|c|}
\hline 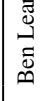 & & & 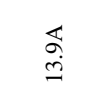 & $\underset{\dot{m}}{\stackrel{\infty}{r}}$ & U. & $\begin{array}{l}\text { U్ } \\
\text { ळ̆ }\end{array}$ & 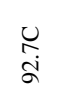 & $\stackrel{\text { a }}{\stackrel{0}{0}}$ & 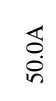 & $\begin{array}{l}\stackrel{\infty}{f} \\
\stackrel{\infty}{\rightarrow}\end{array}$ & m & 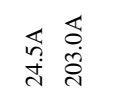 & $\begin{array}{l}u \\
u \\
\stackrel{+}{q}\end{array}$ & 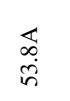 & $\begin{array}{l}\mathbb{1} \\
\dot{m}\end{array}$ & $\begin{array}{l}\text { जू } \\
\text { ले }\end{array}$ & 芯 & 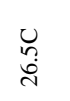 & $\begin{array}{l}0 \\
\stackrel{0}{n} \\
i n\end{array}$ \\
\hline 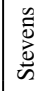 & & & $\begin{array}{l}U_{\infty} \\
\text { D. }\end{array}$ & $\stackrel{\overleftrightarrow{J}}{\stackrel{J}{J}}$ & $\begin{array}{l}\mathbb{d} \\
\text { g }\end{array}$ & $\begin{array}{l}\mathbb{S} \\
\stackrel{0}{\Xi}\end{array}$ & $\begin{array}{l}\stackrel{9}{+} \\
\stackrel{+}{I}\end{array}$ & $\stackrel{\mathbb{n}}{\stackrel{\Xi}{I}}$ & $\begin{array}{l}\infty \\
\text { 心े } \\
\text { हn }\end{array}$ & $\begin{array}{c}\stackrel{\infty}{m} \\
\text { b }\end{array}$ & 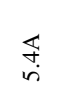 & 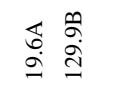 & $\begin{array}{l}\overleftarrow{\infty} \\
\stackrel{0}{0}\end{array}$ & $\stackrel{m}{\stackrel{9}{\dot{g}}}$ & $\begin{array}{l}\text { m} \\
\dot{0} \\
\dot{i}\end{array}$ & $\begin{array}{l}\overleftarrow{d} \\
\text { d. }\end{array}$ & $\begin{array}{l}n \\
n \\
\text { i }\end{array}$ & $\begin{array}{l}\stackrel{n}{\dot{g}} \\
\dot{g}\end{array}$ & 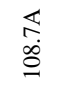 \\
\hline 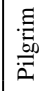 & & & 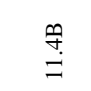 & $\underset{\stackrel{f}{f}}{\stackrel{\mathscr{q}}{+}}$ & $\begin{array}{l}\stackrel{p}{0} \\
\dot{m}\end{array}$ & $\stackrel{\oplus}{\mathbb{f}}$ & 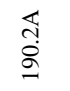 & $\stackrel{m}{=}$ & $\begin{array}{l}q \\
\stackrel{q}{\sigma}\end{array}$ & 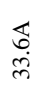 & 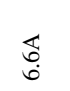 & 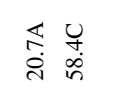 & $\begin{array}{l}\stackrel{m}{a} \\
\dot{g}\end{array}$ & 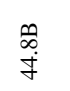 & 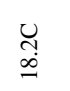 & $\stackrel{m}{\stackrel{m}{m}}$ & 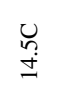 & 离 & $\begin{array}{l}\text { के } \\
\dot{\infty}\end{array}$ \\
\hline & $\sum$ & & $\begin{array}{l}0 \\
m \\
0 \\
+1 \\
m \\
+ \\
+\end{array}$ & $\begin{array}{l}00 \\
\overrightarrow{0} \\
+1 \\
3 \\
3\end{array}$ & $\begin{array}{l}\vec{y} \\
0 \\
+1 \\
+ \\
\Xi \\
\Xi\end{array}$ & $\begin{array}{l}\ddot{y} \\
m \\
0 \\
+1 \\
0 \\
0 \\
m\end{array}$ & $\begin{array}{l}i \\
i \\
+1 \\
\infty \\
\infty \\
\infty \\
\infty\end{array}$ & $\begin{array}{l}\text { त् } \\
0 \\
+1 \\
+1 \\
\\
=\end{array}$ & $\begin{array}{l}z \\
+ \\
0 \\
+1 \\
0 \\
o \\
+\end{array}$ & 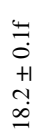 & $\begin{array}{l}= \\
\overrightarrow{0} \\
+1 \\
+\dot{+}\end{array}$ & 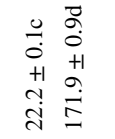 & $\begin{array}{l}0 \\
0 \\
0 \\
0 \\
+1 \\
0 \\
0 \\
0\end{array}$ & 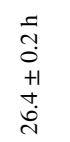 & 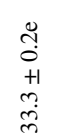 & $\begin{array}{l}\ddot{\forall} \\
=0 \\
0 \\
+1 \\
0 \\
\infty \\
0\end{array}$ & $\begin{array}{l}\tilde{5} \\
\vdots \\
+ \\
+1 \\
\dot{j}\end{array}$ & \begin{tabular}{l}
$\because$ \\
\hdashline \\
0 \\
+1 \\
$\infty$ \\
$\infty$ \\
$\infty$
\end{tabular} & $\begin{array}{l}\ddot{y} \\
\vdots \\
0 \\
+1 \\
\infty \\
\infty \\
\dot{y}\end{array}$ \\
\hline & $\sum$ & & $\begin{array}{l}\vec{T} \\
0 \\
+1 \\
+ \\
\Xi\end{array}$ & $\begin{array}{l}0 \\
\circ \\
0 \\
+1 \\
+ \\
+\end{array}$ & 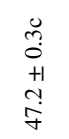 & 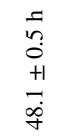 & 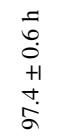 & $\begin{array}{l}\infty \\
0 \\
0 \\
+1 \\
m \\
0\end{array}$ & $\begin{array}{l}0 \\
\tilde{m} \\
0 \\
+1 \\
+1 \\
0 \\
0 \\
+\end{array}$ & $\begin{array}{l}\infty \\
\stackrel{0}{0} \\
+1 \\
+1 \\
\infty \\
= \\
=\end{array}$ & $\begin{array}{l}\ddot{b} \\
0 \\
+1 \\
+1 \\
0 \\
\dot{r}\end{array}$ & 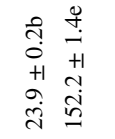 & $\begin{array}{l}+ \\
+ \\
0 \\
+1 \\
\stackrel{\infty}{\infty} \\
n\end{array}$ & $\begin{array}{l}0 \\
\infty \\
0 \\
+1 \\
0 \\
0 \\
0\end{array}$ & $\begin{array}{l}\vec{D} \\
0 \\
0 \\
+1 \\
0 \\
0 \\
0\end{array}$ & $\begin{array}{l}\overrightarrow{3} \\
0 \\
+1 \\
0 \\
\tilde{d}\end{array}$ & $\begin{array}{l}0 \\
m \\
0 \\
+1 \\
m \\
m \\
m\end{array}$ & $\begin{array}{l}= \\
0 \\
+1 \\
0 \\
0 \\
\infty\end{array}$ & $\begin{array}{l}i \overrightarrow{5} \\
0 \\
+1 \\
+ \\
\dot{0}\end{array}$ \\
\hline & $\sum_{n}$ & & $\begin{array}{l}\text { Ĩ } \\
0 \\
+1 \\
n \\
0 \\
0\end{array}$ & $\begin{array}{l}\dot{U} \\
0 \\
+1 \\
+1 \\
m \\
m\end{array}$ & 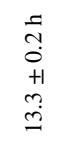 & $\begin{array}{l}\bar{m} \\
\tilde{0} \\
+1 \\
+ \\
y \\
\tilde{m}\end{array}$ & $\begin{array}{l}5 \\
b \\
0 \\
0 \\
+1 \\
0 \\
\vdots \\
0\end{array}$ & 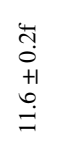 & $\begin{array}{l}n \\
n \\
+1 \\
n \\
n \\
n\end{array}$ & $\begin{array}{l}= \\
\\
+ \\
+1 \\
0 \\
\stackrel{0}{0}\end{array}$ & $\begin{array}{l}- \\
0 \\
0 \\
+1 \\
+ \\
\dot{+}\end{array}$ & 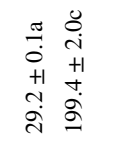 & $\begin{array}{l}\ddot{y} \\
0 \\
0 \\
+1 \\
\infty \\
n \\
n\end{array}$ & $\begin{array}{l}\ddot{a} \\
0 \\
+ \\
+1 \\
\infty \\
\infty \\
\infty\end{array}$ & $\begin{array}{l}\ddot{y} \\
0 \\
+1 \\
+ \\
\dot{\vec{N}}\end{array}$ & $\begin{array}{l}7 \\
z \\
0 \\
+1 \\
0 \\
j \\
j\end{array}$ & $\begin{array}{l}n \\
-1 \\
0 \\
+1 \\
n \\
\tilde{C}\end{array}$ & 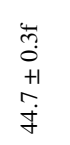 & $\begin{array}{l}m \\
0 \\
+1 \\
+ \\
\dot{0} \\
\dot{d}\end{array}$ \\
\hline 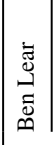 & $\Sigma$ & & $\begin{array}{l}\tilde{y} \\
0 \\
+1 \\
m \\
\ddot{n}\end{array}$ & $\begin{array}{l}0 \\
0 \\
0 \\
+1 \\
+ \\
\stackrel{+}{+}\end{array}$ & $\begin{array}{l}\stackrel{0}{0} \\
+1 \\
+ \\
\dot{m}\end{array}$ & $\begin{array}{l}\stackrel{F}{f} \\
\dot{0} \\
+1 \\
\infty \\
\dot{q}\end{array}$ & $\begin{array}{l}: \Xi \\
: \\
+1 \\
0 \\
\dot{+} \\
\infty\end{array}$ & $\begin{array}{l}00 \\
-0 \\
0 \\
+1 \\
m \\
0\end{array}$ & $\begin{array}{l}8 \\
0 \\
0 \\
+1 \\
\infty \\
\infty \\
\dot{\sigma}\end{array}$ & $\begin{array}{l}\vec{C} \\
\vdots \\
+1 \\
\infty \\
\dot{\vec{N}} \\
\overrightarrow{+}\end{array}$ & $\begin{array}{l}\stackrel{0}{0} \\
\dot{0} \\
+1 \\
\dot{0}\end{array}$ & 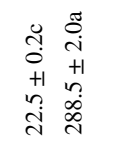 & $\begin{array}{l}\vec{n} \\
0 \\
+ \\
+1 \\
0 \\
0 \\
0\end{array}$ & $\begin{array}{l}\tilde{n} \\
0 \\
+1 \\
+1 \\
n \\
0 \\
= \\
=\end{array}$ & $\begin{array}{l}\text { g } \\
0 \\
+1 \\
+1 \\
\dot{0} \\
q\end{array}$ & 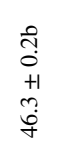 & $\begin{array}{l}0 \\
0 \\
0 \\
+1 \\
n \\
n \\
j\end{array}$ & 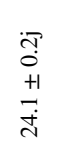 & $\begin{array}{l}\infty \\
0 \\
0 \\
0 \\
+1 \\
0 \\
0 \\
0\end{array}$ \\
\hline & $\sum$ & & $\begin{array}{l}\vec{m} \\
\dot{0} \\
+1 \\
\stackrel{y}{\Xi}\end{array}$ & $\begin{array}{l}\tilde{n} \\
0 \\
+1 \\
+\infty \\
\infty\end{array}$ & 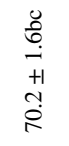 & $\begin{array}{l}\underset{a}{i} \\
+1 \\
+1 \\
m \\
\tilde{a}\end{array}$ & $\begin{array}{l}y \\
+ \\
0 \\
+1 \\
\infty \\
0 \\
0\end{array}$ & 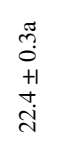 & $\begin{array}{l}i n \\
0 \\
+1 \\
0 \\
\dot{0} \\
\dot{j}\end{array}$ & 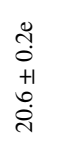 & $\begin{array}{l}\dot{00} \\
\overrightarrow{0} \\
+1 \\
\vec{n} \\
\vec{n}\end{array}$ & 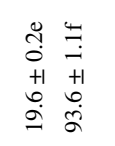 & $\begin{array}{l}0 \\
ٌ \\
0 \\
+1 \\
+1 \\
\\
\end{array}$ & $\begin{array}{l}0 \\
0 \\
0 \\
0 \\
0 \\
\dot{0} \\
\text { in }\end{array}$ & $\begin{array}{l}= \\
= \\
0 \\
+1 \\
\stackrel{5}{=}\end{array}$ & $\begin{array}{l}\dot{n} \\
\stackrel{2}{0} \\
+1 \\
0 \\
\dot{g}\end{array}$ & 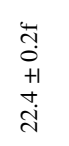 & \begin{tabular}{l}
$:$ \\
$\stackrel{0}{0}$ \\
+1 \\
\multirow{1}{*}{} \\
$\dot{H}$
\end{tabular} & $\begin{array}{l}0 \\
\stackrel{n}{g} \\
+1 \\
n \\
n \\
n \\
\end{array}$ \\
\hline & $\sum$ & & $\begin{array}{l}= \\
\overrightarrow{0} \\
+1 \\
+ \\
\dot{0}\end{array}$ & $\begin{array}{l}0 \\
\stackrel{0}{0} \\
+1 \\
0 \\
\dot{+}\end{array}$ & 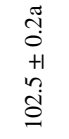 & $\begin{array}{l}8 \\
0 \\
0 \\
+1 \\
1 \\
1 \\
0\end{array}$ & 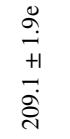 & $\begin{array}{l}\vec{v} \\
0 \\
0 \\
+1 \\
n \\
\dot{J}\end{array}$ & $\begin{array}{l}o n \\
0 \\
0 \\
+1 \\
+1 \\
+ \\
\dot{m}\end{array}$ & $\begin{array}{l}\vec{m} \\
0 \\
+1 \\
+1 \\
n \\
n\end{array}$ & $\begin{array}{l}\Delta \\
0 \\
0 \\
+1 \\
0 \\
\dot{b}\end{array}$ & 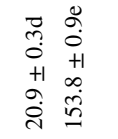 & $\begin{array}{l}\stackrel{a}{\sim} \\
0 \\
0 \\
+1 \\
o \\
\infty \\
\infty\end{array}$ & $\begin{array}{l}4 \\
\dot{b} \\
0 \\
+1 \\
n \\
n \\
m\end{array}$ & $\begin{array}{l}\breve{a} \\
0 \\
+1 \\
+\vec{j}\end{array}$ & 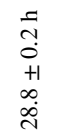 & $\begin{array}{l}\vec{D} \\
0 \\
0 \\
+1 \\
0 \\
0 \\
0 \\
0\end{array}$ & $\begin{array}{l}\infty \\
+ \\
0 \\
+1 \\
+1 \\
0 \\
\infty \\
\infty\end{array}$ & $\begin{array}{l}0 \\
\stackrel{0}{0} \\
+1 \\
0 \\
\dot{+}\end{array}$ \\
\hline & $\sum_{n}$ & & $\begin{array}{l}\infty \\
\dot{0} \\
+1 \\
+1 \\
?\end{array}$ & $\begin{array}{l}\stackrel{0}{0} \\
0 \\
+1 \\
n \\
0\end{array}$ & $\begin{array}{l}n \\
\vdots \\
+1 \\
+1 \\
\infty \\
0\end{array}$ & $\begin{array}{l}2 \\
0 \\
+1 \\
+1 \\
8 \\
0\end{array}$ & 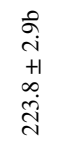 & 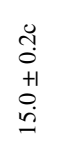 & \begin{tabular}{l} 
s \\
$n$ \\
0 \\
+1 \\
+1 \\
\multirow{j}{m}{} \\
m.
\end{tabular} & $\begin{array}{l}\text { ते } \\
0 \\
+1 \\
+1 \\
\infty \\
\end{array}$ & $\begin{array}{l}0 \\
0 \\
+1 \\
+1 \\
0 \\
0\end{array}$ & 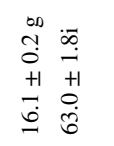 & $\begin{array}{l}f \\
+ \\
+ \\
+1 \\
m \\
+1 \\
i\end{array}$ & $\begin{array}{l}0 \\
0 \\
0 \\
+1 \\
0 \\
i\end{array}$ & $\begin{array}{l}\text { ¿̦ } \\
0 \\
+1 \\
\hat{\sigma}\end{array}$ & 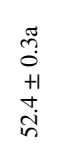 & 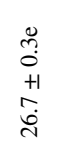 & $\begin{array}{l}7 \\
+ \\
0 \\
+1 \\
-i \\
i\end{array}$ & $\begin{array}{l}\frac{\pi}{S} \\
\stackrel{+}{+1} \\
\stackrel{\vec{I}}{+}\end{array}$ \\
\hline 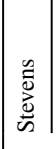 & $\Xi$ & & $\begin{array}{l}\tilde{n} \\
0 \\
+1 \\
n \\
=\end{array}$ & $\begin{array}{l}0 \\
0 \\
0 \\
+1 \\
\text { Y } \\
+\end{array}$ & \begin{tabular}{l}
0 \\
0 \\
0 \\
+1 \\
$y$ \\
\multirow{4}{4}{}
\end{tabular} & $\begin{array}{l}\overrightarrow{0} \\
0 \\
0 \\
+1 \\
y \\
\forall \\
b\end{array}$ & 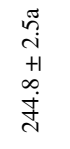 & $\begin{array}{l}0 \\
0 \\
+1 \\
0 \\
\infty \\
0\end{array}$ & $\begin{array}{l}m \\
o \\
+1 \\
\dot{j} \\
\dot{j}\end{array}$ & 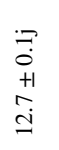 & $\begin{array}{l}ت \\
\\
+ \\
+1 \\
\tilde{+}\end{array}$ & 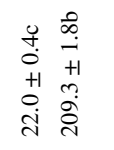 & 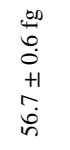 & $\begin{array}{l}\infty \\
m \\
0 \\
+1 \\
+\infty \\
m\end{array}$ & 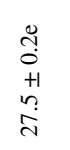 & $\begin{array}{l}\infty \\
0 \\
0 \\
+1 \\
+ \\
\stackrel{i}{2}\end{array}$ & $\begin{array}{l}\vec{n} \\
0 \\
0 \\
+1 \\
n \\
0 \\
\infty \\
d\end{array}$ & $\begin{array}{l}i \vec{n} \\
0 \\
++1 \\
n \\
n \\
m\end{array}$ & $\begin{array}{l}\text { 芦 } \\
0 \\
+1 \\
0 \\
0 \\
0 \\
\infty\end{array}$ \\
\hline & $\Sigma$ & & $\begin{array}{l}\text { ज̃ } \\
0 \\
0 \\
+1 \\
= \\
\Xi\end{array}$ & $\begin{array}{l}\text { ลิ } \\
\text { ஸे } \\
+1 \\
\text { +1 } \\
\text { in }\end{array}$ & $\begin{array}{l}\overrightarrow{7} \\
0 \\
+1 \\
0 \\
\dot{m}\end{array}$ & $\begin{array}{l}0 \\
0 \\
0 \\
+1 \\
0 \\
\dot{1}\end{array}$ & 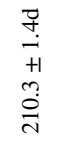 & 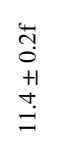 & $\begin{array}{l}0 \\
\tilde{m} \\
0 \\
+1 \\
0 \\
\dot{y}\end{array}$ & $\begin{array}{l}0 \\
0 \\
0 \\
+1 \\
0 \\
\dot{m} \\
m\end{array}$ & 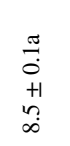 & 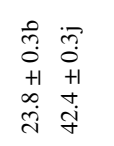 & $\begin{array}{l}\tilde{g} \\
\stackrel{0}{0} \\
+1 \\
\overrightarrow{0} \\
i\end{array}$ & $\begin{array}{l}8 \\
0 \\
0 \\
+1 \\
2 \\
\Sigma \\
R\end{array}$ & $\begin{array}{l}\infty \\
1 \\
\vdots \\
+1 \\
+1 \\
o \\
\dot{I}\end{array}$ & $\begin{array}{l}\vec{r} \\
0 \\
0 \\
+1 \\
m \\
\dot{q}\end{array}$ & $\begin{array}{l}= \\
+ \\
0 \\
+1 \\
+ \\
\infty \\
0\end{array}$ & $\begin{array}{l}\frac{\pi}{0} \\
0 \\
+1 \\
01 \\
0\end{array}$ & $\begin{array}{l}2 \\
0 \\
0 \\
+1 \\
+ \\
\dot{0}\end{array}$ \\
\hline & $\sum$ & & $\begin{array}{l}0 \\
0 \\
0 \\
+1 \\
+ \\
\dot{0}\end{array}$ & $\begin{array}{l}0 \\
\stackrel{0}{0} \\
0 \\
+1 \\
m \\
+\end{array}$ & $\begin{array}{l}\text { f. } \\
0 \\
+1 \\
+ \\
0 \\
\text { d }\end{array}$ & $\begin{array}{l}\vec{\infty} \\
0 \\
0 \\
+1 \\
\infty \\
\dot{d}\end{array}$ & $\begin{array}{l}\stackrel{0}{\vec{i}} \\
+1 \\
\dot{\vec{n}} \\
\vec{i}\end{array}$ & $\begin{array}{l}\stackrel{0}{0} \\
0 \\
+1 \\
0 \\
\stackrel{1}{J}\end{array}$ & $\begin{array}{l}0 \\
ٌ \\
+1 \\
+1 \\
\stackrel{j}{y}\end{array}$ & 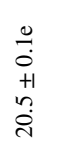 & $\begin{array}{l}\text { on } \\
\tilde{a} \\
0 \\
+1 \\
\vec{n}\end{array}$ & 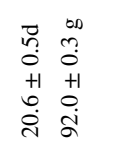 & $\begin{array}{l}\overline{3} \\
0 \\
+1 \\
\text { +े } \\
\text { ते }\end{array}$ & $\begin{array}{l}\text { an } \\
0 \\
0 \\
+1 \\
0 \\
0 \\
\dot{m}\end{array}$ & $\begin{array}{l}\vec{j} \\
0 \\
+1 \\
0 \\
0\end{array}$ & $\begin{array}{l}\bar{n} \\
0 \\
+1 \\
\stackrel{4}{4}\end{array}$ & $\begin{array}{l}\overrightarrow{5} \\
\dot{0} \\
+1 \\
\stackrel{+}{ \pm}\end{array}$ & $\begin{array}{l}0 \\
\infty \\
0 \\
+1 \\
\infty \\
\infty \\
\dot{q}\end{array}$ & $\begin{array}{l}m \\
0 \\
+1 \\
+1 \\
\vdots \\
\vdots\end{array}$ \\
\hline & $\sum$ & & $\begin{array}{l}0 \\
0 \\
0 \\
+1 \\
+1 \\
=\end{array}$ & $\begin{array}{l}8 \\
0 \\
0 \\
+1 \\
n \\
+\end{array}$ & $\begin{array}{l}\overrightarrow{0} \\
0 \\
+1 \\
+1 \\
\dot{q}\end{array}$ & $\begin{array}{l}0 \\
0 \\
+1 \\
+1 \\
0 \\
0\end{array}$ & $\begin{array}{l}\vec{b} \\
\dot{+} \\
++1 \\
0 \\
2 \\
2 \\
2\end{array}$ & $\begin{array}{l}+ \\
0 \\
0 \\
+1 \\
m \\
=\end{array}$ & $\begin{array}{l}\vec{m} \\
0 \\
+1 \\
+1 \\
\hat{\sigma}\end{array}$ & 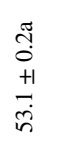 & $\begin{array}{l}\text { तิ } \\
+1 \\
+1 \\
\tilde{b}\end{array}$ & 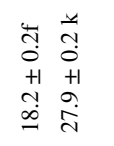 & 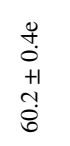 & $\begin{array}{l}z \\
0 \\
+1 \\
n \\
\infty \\
\infty\end{array}$ & 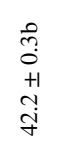 & $\begin{array}{l}\stackrel{0}{0} \\
+1 \\
\dot{+}\end{array}$ & $\begin{array}{l}\vec{j} \\
\dot{+} \\
+1 \\
\stackrel{+}{+}\end{array}$ & $\begin{array}{l}= \\
0 \\
0 \\
+1 \\
m \\
m \\
m\end{array}$ & $\begin{array}{l}\tilde{R} \\
\dot{0} \\
+1 \\
\dot{8}\end{array}$ \\
\hline $\begin{array}{l}\frac{E}{E} \\
\frac{E_{0}}{2}\end{array}$ & $\Xi$ & & $\begin{array}{l}\vec{y} \\
0 \\
+1 \\
0 \\
0\end{array}$ & 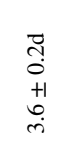 & 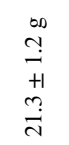 & $\begin{array}{l}o n \\
\stackrel{\infty}{0} \\
\dot{+} \\
+1 \\
n \\
\dot{n} \\
i n\end{array}$ & $\begin{array}{l}\infty \\
\stackrel{b}{0} \\
i \\
+1 \\
0 \\
\dot{+} \\
\dot{I}\end{array}$ & 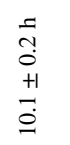 & $\begin{array}{l}i \\
0 \\
+ \\
+1 \\
0 \\
i \\
j\end{array}$ & 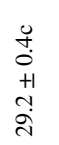 & $\begin{array}{l}= \\
0 \\
0 \\
+1 \\
3 \\
0\end{array}$ & 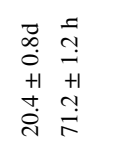 & $\begin{array}{l}i \\
i n \\
0 \\
+1 \\
n \\
0 \\
0 \\
n\end{array}$ & $\begin{array}{l}0 \\
0 \\
0 \\
+1 \\
+1 \\
\stackrel{0}{m}\end{array}$ & $\begin{array}{l}\overrightarrow{0} \\
\dot{0} \\
+1 \\
\dot{0}\end{array}$ & $\begin{array}{l}\vec{m} \\
0 \\
+1 \\
+1 \\
0\end{array}$ & $\begin{array}{l}\vec{y} \\
0 \\
+1 \\
\stackrel{+}{\Xi}\end{array}$ & $\begin{array}{l}0 \\
0 \\
0 \\
+1 \\
n \\
0 \\
0\end{array}$ & $\begin{array}{l}5 \\
5 \\
0 \\
+1 \\
\infty \\
\infty \\
\stackrel{1}{1}\end{array}$ \\
\hline & & & 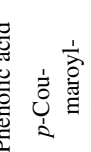 & & & & & & & & $\sum_{\infty}^{0}$ & 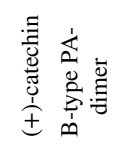 & 商表 & $\sum_{\dot{4}}^{\infty}$ & 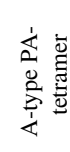 & 总贯 & & 窝. & 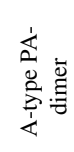 \\
\hline
\end{tabular}




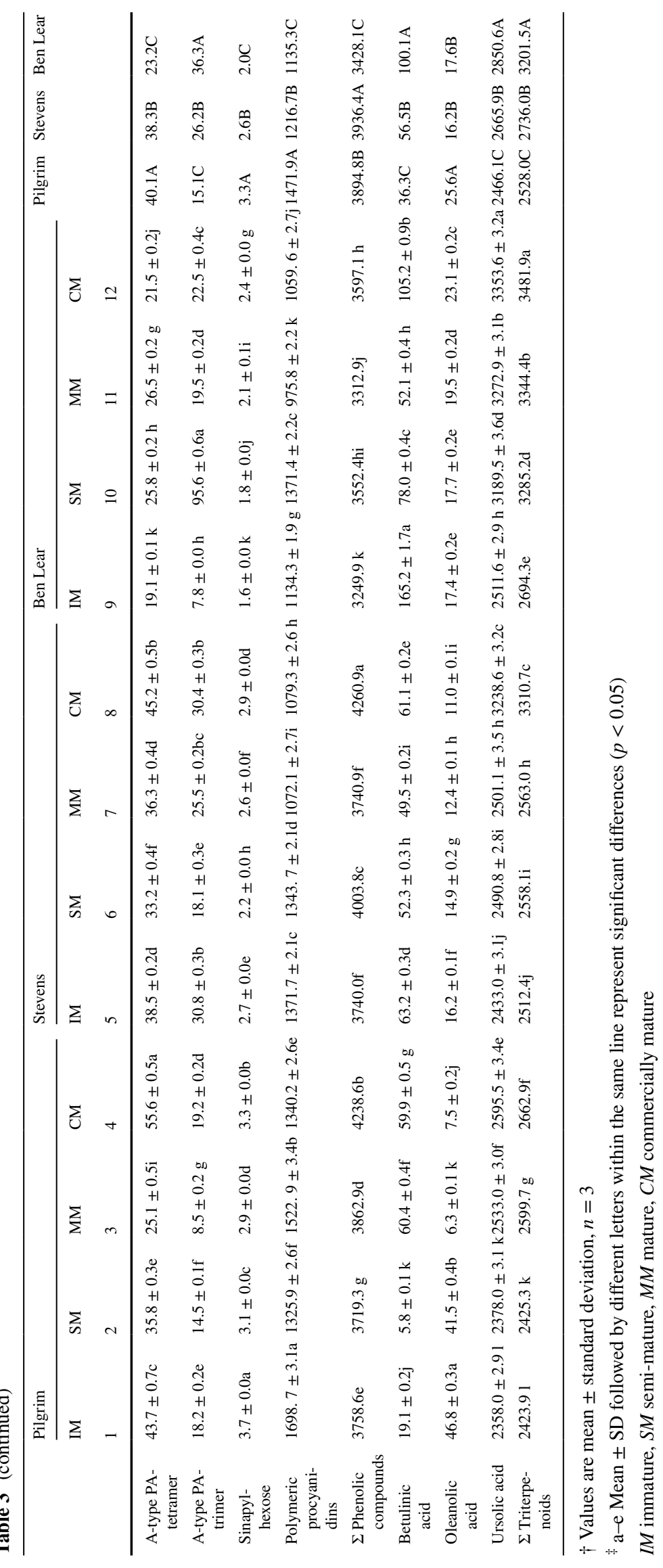




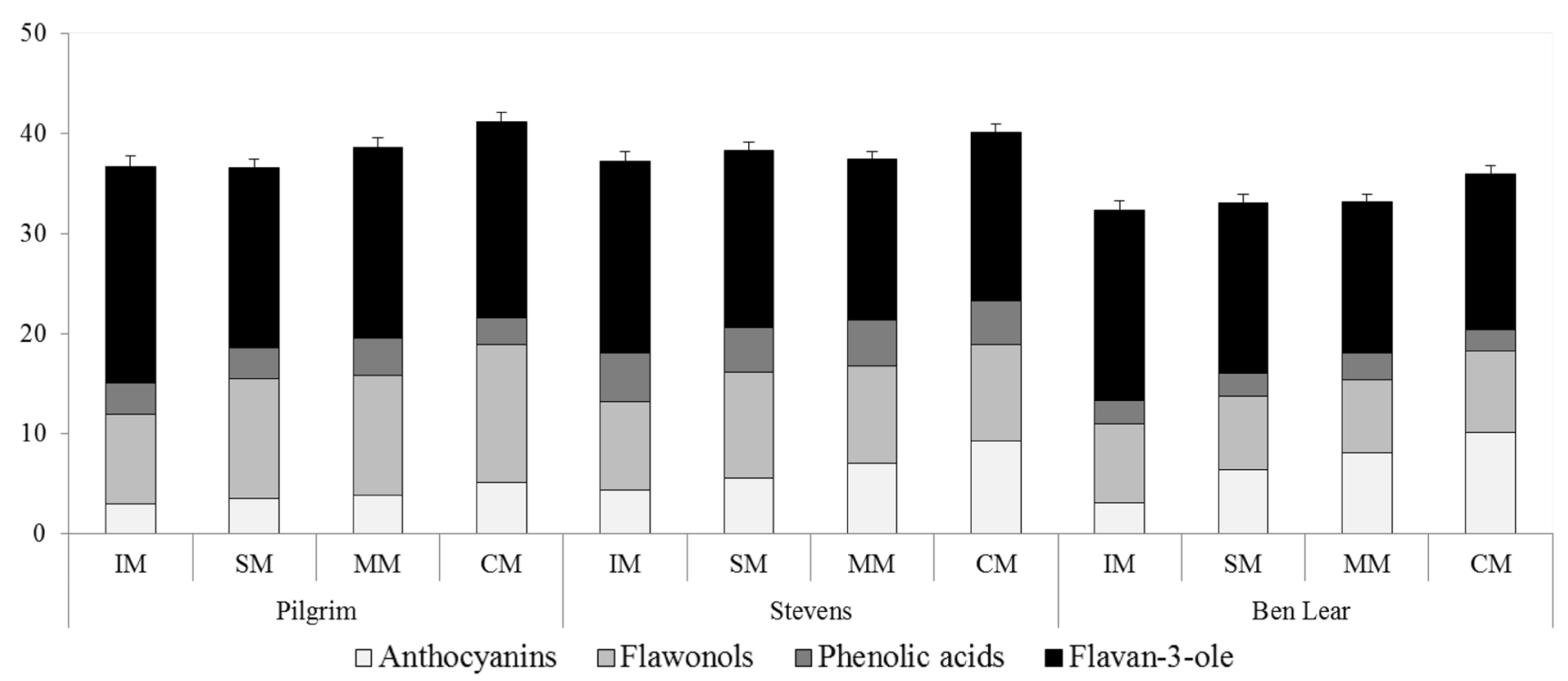

Fig. 2 Content of polyphenolic compounds $(\mathrm{g} / \mathrm{kg} \mathrm{dm})$ (values are mean \pm standard deviation, $n=3)$ of cranberry fruits of three cultivars harvested at different maturity stages. $I M$ immature, $S M$ semi-mature, $M M$ mature, $C M$ commercially mature

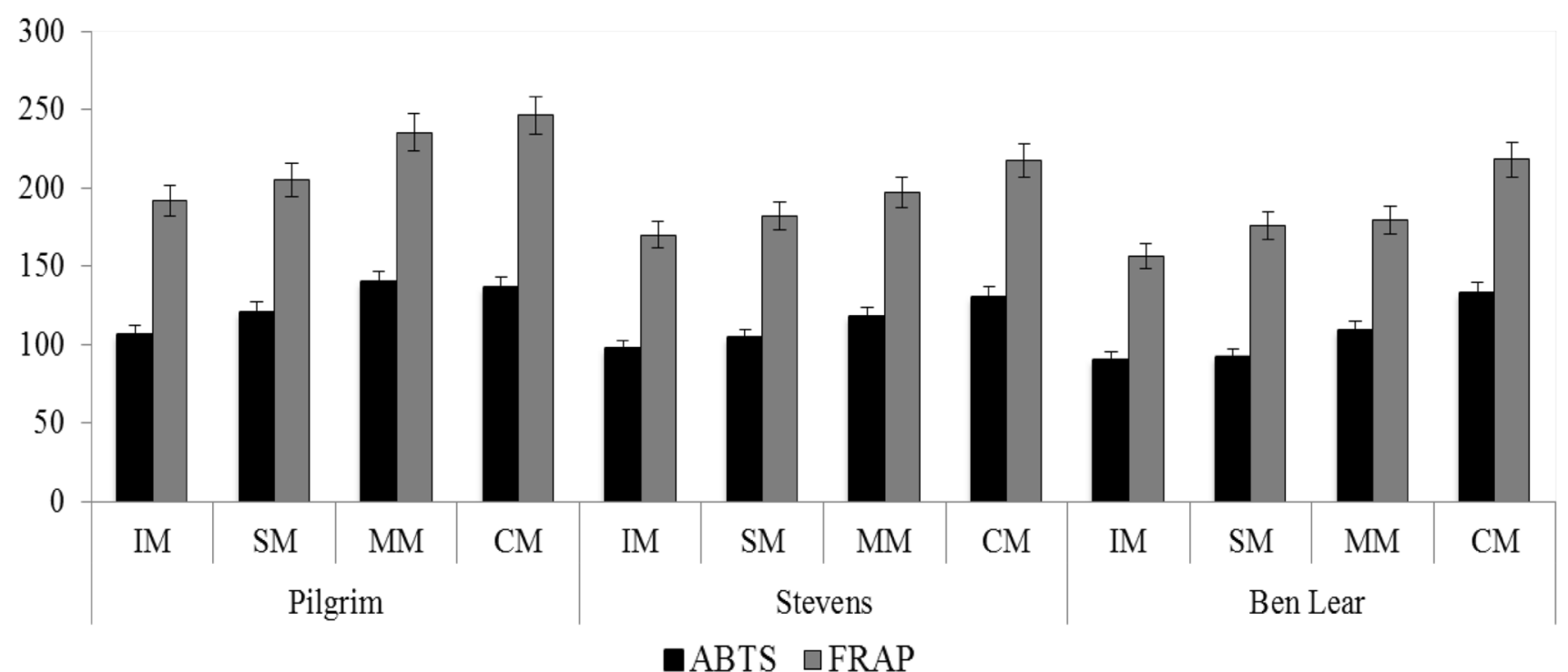

Fig. 3 Antioxidant activity ( $\mu \mathrm{mol}$ Trolox/g dm) (values are mean \pm standard deviation, $n=3$ ) of fruits in cranberry three cultivars harvested at different maturity stages. IM immature, $S M$ semi-mature, $M M$ mature, $C M$ commercially mature

et al. [21] the content of phenolic acids in cranberry cvs. 'Pilgrim', 'Stevens' and 'Ben Lear' was 1.2, 1.1, and 1.5 times higher than the same cultivars in this study in the commercially mature phase. The content of phenolic acids decreased remarkably in tested cultivars of cranberry fruits from 36.5 to $12.3 \%$ from cvs. 'Stevens' to 'Ben Lear', respectively. In addition, during fruit ripening, the concentration of phenolic acids in cv. 'Ben Lear' slightly decreased (by around 2.8\%) from the immature to semi-mature phase and then increased from the semi-mature mature phase by around $15.1 \%$, and the last level was decreased from the mature to commercially mature phase by around $21.6 \%$; in cv. 'Pilgrim'-26.5, 0.02, and 5.9\%, respectively, and in cv. 'Stevens'-34.5, 2.4, and 5.3\%, respectively. During different maturity phases of the plant, phenolic acid content is changed, for example, phenolic acids content increases during ripening of tomatoes. In ripe strawberries, the phenolic content is higher than in immature ones; in the case of 
apples, the opposite trend is observed [33]. Similar changes are observed in different varieties of cranberries. The major phenolic acid compounds in all cranberry cultivars were caffeoyl hexoside (from 34.6 to $54.1 \%$ of total phenolic acids) and caffeoyl dihexoside (from 16.5 to $35.0 \%$ ). Furthermore, the decrease of phenolic acid content is also confirmed in research by Macheix and Fleuriet [34], Ferreyra et al. [27], and Dragovic-Uzelac et al. [35].

\section{Identification and quantification of triterpenoids in cranberry fruits}

Table 3 shows the data after determination of triterpenoids in the fruits of three cultivars of cranberry fruits of different maturity stages. The detected compounds were identified as betulinic, ursolic, and oleanolic acids based on their molecular ion $[\mathrm{M}-\mathrm{H}]^{-}$at $\mathrm{m} / \mathrm{z} 455.3$, MS profiles with the fragmentation pathways, UV-Vis spectra, and the retention times (Rt) of authentic standards.

The average composition of triterpenoids in all tested cranberry cultivars harvested at different maturity stages ranged from 2528.0 in cv. 'Pilgrim' to $3201.5 \mathrm{mg} / \mathrm{kg} \mathrm{dm}$ in cv. 'Ben Lear'. The content of triterpenoids increased remarkably in fruit cvs. 'Pilgrim', 'Stevens' and 'Ben Lear' ripening $(9.0,24.1$, and $22.6 \%$, respectively), from the immature to the commercially mature stage. Furthermore, during fruit ripening, the concentration of triterpenoids in cv. 'Pilgrim' increased from the immature to semi-mature phase by around $0.1 \%$, from the semi-mature mature phase by around $6.7 \%$, and from the mature to commercially mature phase by around $2.4 \%$; in cv. 'Stevens'-1.8, 0.2, and $22.6 \%$, respectively, and in cv. 'Ben Lear'-18.0, 1.8, and $3.9 \%$, respectively. In addition, the major triterpenoid compound in cranberry fruits of analyzed cultivars was ursolic acid; it ranged from 22.7 to $32.2 \%$ of total triterpenoids. However, in cvs. 'Pilgrim' and 'Stevens', a drop in ursolic acid content of around 84.0 and $32.0 \%$ was noted. According to Kondo [36], the concentration of ursolic acid in cranberry fruits ranges from 60 to $110 \mathrm{mg} / 100 \mathrm{~g} \mathrm{fm}$. Furthermore, Szakiel et al. [37] reported that ursolic acid was the predominant triterpenoid compound present in cranberry (20\% of all wax extract), sweet cherry (60\%), and apple (98\%). McKenna et al. [38] observed the presence of polymeric terpenes belonging to the group of phytosterols in cranberry pomace and wax coat (Fig. 2).

\section{Antioxidant capacity}

Results of the antioxidant capacity of tested cranberry cultivars grown at different maturity stages measured by the free radical-scavenging activity (ABTS) and the ferric reducing/antioxidant power (FRAP) methods are presented in Fig. 3. Significant differences were observed among tested cultivars and breeding clones according to these assays. The average antioxidant capacity in cranberry fruits of analyzed cultivars harvested at different maturity stages in the ABTS assay was $124.7 \mu \mathrm{mol}$ Trolox/g dm in cv. 'Pilgrim', and it was 9.8 and $14.9 \%$
Fig. 4 PCA mean showing the relationship among bioactive compounds and antioxidant activity of cranberry fruits of three cultivars. TPC total phenolic compounds, F3o flavan3-ols, TS total sugar, TT total triterpenoids, $F L$ flavonoids, $P P$ polymeric procyanidins, $P A$ phenolic acids, $A N T$ anthocyanins

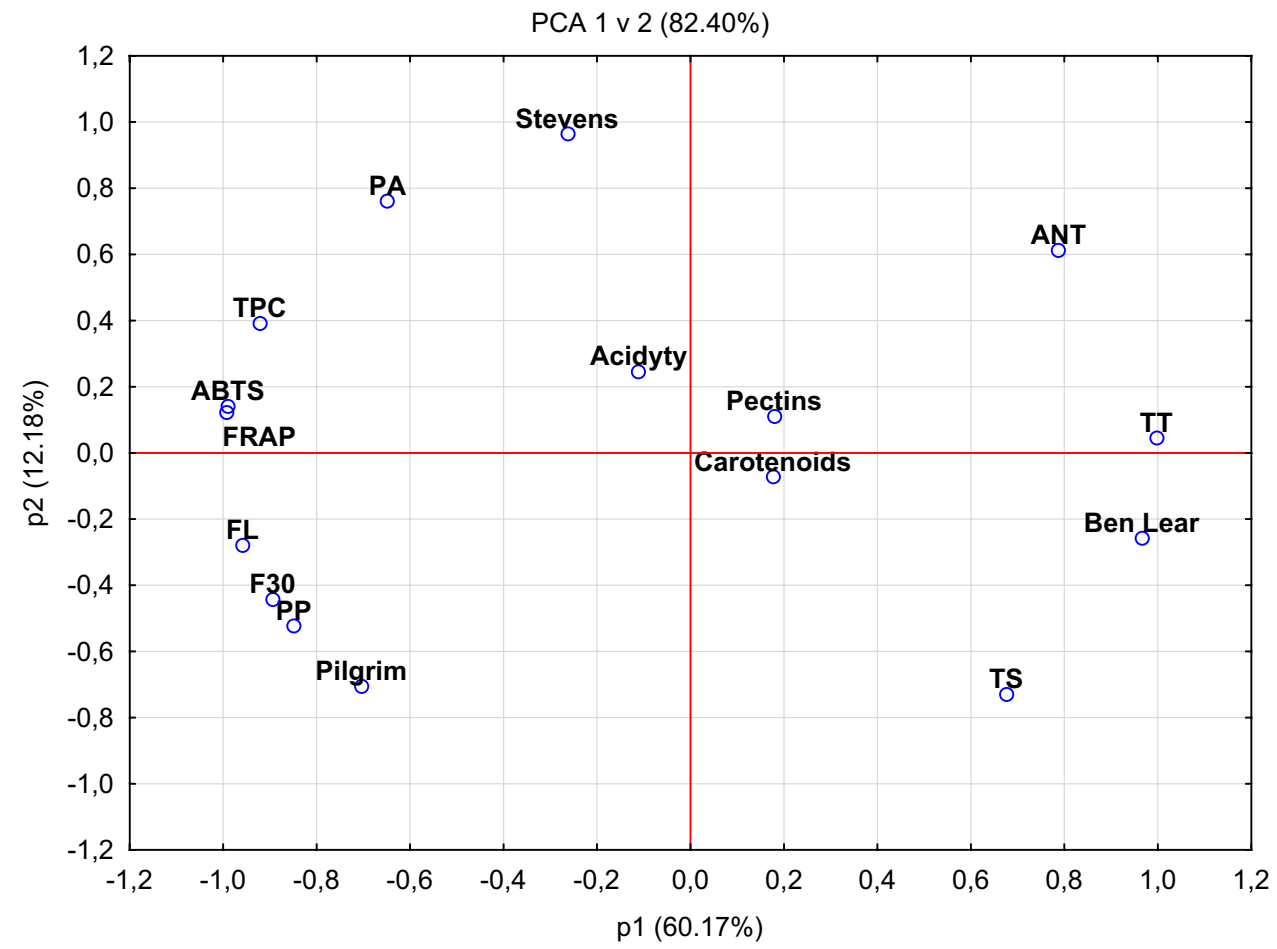


higher than cvs. 'Stevens' and 'Ben Lear', respectively, while, in the FRAP assay, it was $219.6 \mu \mathrm{mol} \mathrm{Trolox} / \mathrm{g} \mathrm{dm}$ in cv. 'Pilgrim' and it was 12.7 and $16.9 \%$ higher than cvs. 'Stevens' and 'Ben Lear', respectively. According to Oszmiański et al. [28], the antioxidant capacity measured by the ABTS and FRAP assay in cranberry cultivars 'Pilgrim', 'Stevens', and 'Ben Lear' was around 2 times higher and around 3 times lower than antioxidant capacity in the same cultivars of cranberry harvested at different maturity stages. Namiesnik et al. [39] reported that antioxidant capacity measured by ABTS assay ranged from 10.72 to $72.76 \mu \mathrm{mol} / \mathrm{g} \mathrm{dm}$, while FRAP assay values ranged from 3.28 to $26.97 \mu \mathrm{mol} / \mathrm{g} \mathrm{dm}$, which was lower than our results. The antioxidant capacity (as with the ABTS and FRAP assay) increased remarkably in fruit cvs. 'Pilgrim', 'Stevens', and 'Ben Lear' ripening (ABTS-21.7, 24.9, and 31.9\%, and FRAP-22.1, 21.9, and 28.1, respectively), from the immature to the commercially mature stage. However, during fruit ripening, the antioxidant capacity measured by ABTS and FRAP assay in cv. 'Pilgrim' increased from the immature to the semi-mature phase by around 11.8 and $6.6 \%$, from the semi-mature mature phase by around 11.1 and $12.9 \%$ and from the mature to the commercially mature phase by around 0.2 and $4.4 \%$; in cv. 'Stevens' - 6.5, 11.1, and 9.6 (ABTS assay), and 6.6, 7.7, and 9.4\% (FRAP assay), respectively, and in cv. 'Ben Lear'-2.0, 15.1, and 18.1\% (ABTS assay) and 11.0, 1.9, and 17.7\% (FRAP assay), respectively. Research by Shin et al. [23] and Sreelatha and Padma [40] showed that capacity is increasing in strawberry and Moringa oleifera, and was similar to the results of cranberries harvested at different maturity stages.

\section{Principal component analysis (PCA)}

The study's average results from different maturity stages (1st-immature, IM, 8th-semi-mature, SM, 15th-mature, $\mathrm{MM}$, and 22nd-commercially mature, CM, of September 2016) grown in Poland cranberry cultivars 'Pilgrim', 'Stevens', and 'Ben Lear' in their phytochemical composition and antioxidant activity were emphasized during PCA. Two main PCAs for the analyzed four genotypes grown in Poland accounted for $82.40 \%$ of the total variability, PC1 for $60.19 \%$, and PC2 for $12.18 \%$ (Fig. 4). The results obtained from PCA using the linkage method among groups indicated the presence of four clusters:

1. Stevens with higher concentrations of total phenolic compounds (TPC), phenolic acids (PA), and acidity. In addition, a positive correlation with antioxidant activity (FRAP and ABTS) was detected;
2. Pilgrim with high contents of flavonols, polymeric procyanidins (PP) and total flavan-3-ols (F30) and a positive correlation with antioxidant activity (FRAP and ABTS);

3. Ben Lear with high correlation of carotenoids and total sugar (TS);

4. Anthocyanins (ANT), total triterpenoids (TT), and pectins with a negative correlation with antioxidant activity.

\section{Conclusions}

The composition and amount of basic chemicals, bioactive compounds, and antioxidant activity within fruits such as cranberry is important for their quality and beneficial effects. An investigation of the basic chemicals, bioactive compounds, and antioxidant activity of three cranberry cultivars harvested at different maturity stages was performed in this study. We confirmed quantitative differences of phytochemical compounds and antioxidant capacity in cranberry cultivars in individual phases of growth. Qualitative differences of polyphenols, triterpenoids, and antioxidant activity in the three examined cranberry cultivars during ripening were not observed. 'Pilgrim' cultivar had significantly lower contents in its fruits of active compounds, such as phenolic compounds, triterpenoids, and antioxidant capacity in comparison to the two cvs. 'Stevens' and 'Ben Lear'. The highest amount of bioactive compounds was determined in commercially mature cranberry, decreasing to semi-mature and immature stages of ripening, whereas the changes in concentration of some triterpenoids and polyphenols at semi-mature and commercially mature stages were not uniform. Cranberry fruits can be used for the food processing industry as an important ingredient in good quality food and for the production of health beneficial products; therefore, choosing the right maturity stage and cultivars of the fruit is important. Furthermore, mature cranberry fruits represent a very good and diverse source of active compounds and antioxidant properties and thus should be a valuable component of our daily diet.

Acknowledgements The publication was supported by Wroclaw Centre of Biotechnology, under the program The Leading National Research Centre (KNOW) for the years 2014-2018. The authors thank Elżbiecie Buckiej and Aleksandrze Borak for their technical assistance.

Author contributions Important contributions to design and in preparation of the manuscript: S.L. and J.O. Contributions to sample and analysis experiments: S.L. and J.O. Analysis of the experimental data: S.L. Critical revision for important intellectual content: S.L. and J.O. All authors helped preparing the paper and approved the final version. 


\section{Compliance with ethical standards}

Conflict of interest The authors declare no conflict of interest.

Compliance with ethics requirements All authors declare that this article does not contain any studies with human or animal subjects.

Open Access This article is distributed under the terms of the Creative Commons Attribution 4.0 International License (http://creativecommons.org/licenses/by/4.0/), which permits unrestricted use, distribution, and reproduction in any medium, provided you give appropriate credit to the original author(s) and the source, provide a link to the Creative Commons license, and indicate if changes were made.

\section{References}

1. Neto CC, Dao CA, Salvas MR, Autio WR, Heuvel JEV (2010) J Am Soc Hortic Sci 135(6):494-500

2. Jepson RG, Craig JC (2007) Mol Nutr Food Res 51(6):738-745

3. Özgen M, Palta JP, Smith JD (2002) Post Biol Technol 24(3):291-299

4. Neto CC (2007) J Nutr 137(1):186S-193S

5. Gardner PT, White TA, McPhail DB, Duthie GG (2000) Food Chem 68(4):471-474

6. McKay DL, Blumberg JB (2007) Nutr Rev 65(11):490-502

7. Borowska EJ, Mazur B, Kopciuch RG, Buszewski B (2009) Food TechnolBiotech 47(1):56-61

8. Budryn G, Nebesny E (2006) Bromatol Chem Toksyk 39(2):103

9. De Beer D, Joubert E, Gelderblom WCA, Manley M (2017) S Afr J Enol Vitic 23(2):48-61

10. Oszmiański J, Lachowicz S (2016) Molecules 21(8):1098

11. Jäger S, Trojan H, Kopp T, Laszczyk MN, Scheffler A (2009) Molecules 14(6):2016-2031

12. Loza-Mejía MA, Salazar JR (2015) J Mol Graph Model 62:18-25

13. Yamaguchi H, Noshita T, Kidachi Y, Umetsu H, Hayashi M, Komiyama K, Funayama S, Ryoyama K (2008) J Health Sci 54(6):654-660

14. Horowitz W, Latimer GE (eds) (2005) AOAC International, Maryland

15. Pijanowski E, Mrożewski S, Horubała A, Jarczyk A (1973) PWRiL, Warszawa

16. Lachowicz S, Oszmiański J, Pluta S (2017) Food Chem 235:234-243

17. Lachowicz S, Wojdyło A, Chmielewska J, Oszmiański J (2017) Eur Food Res Technol 1-11
18. Farneti B, Masuero D, Costa F, Magnago P, Malnoy M, Costa G, Vrhovsek U, Mattivi F (2015) J Agric Food Chem 63(10):2750-2759

19. Re R, Pellegrini N, Proteggente A, Pannala A, Yang M, RiceEvans C (1999) Free Radical Biol Med 26(9):1231-1237

20. Benzie IF, Strain JJ (2009) Anal Biochem 239(1):70-76

21. Oszmiański J, Kolniak-Ostek J, Lachowicz S, Gorzelany J, Matłok N (2015) Ind Crop Prod 77:658-665

22. Úwieczkowska A, Kawecki Z, Stanys V (2004) Hort Veg Growing 23(1):36-40

23. Shin Y, Liu RH, Nock JF, Holliday D, Watkins CB (2007) Post Biol Technol 45(3):349-357

24. Mudgil D, Barak S (2013) Int J Biol Macromol 61:1-6

25. Sañudo-Barajas JA, Labavitch J, Greve C, Osuna-Enciso T, MuyRangel D, Siller- Cepeda J (2009) Post Biol Technol 51:158-167

26. Wang SY, Chen CT, Wang CY (2009) Food Chem 112(3):676-684

27. Ferreyra RM, Viña SZ, Mugridge A, Chaves AR (2007) Sci Hortic Amsterdam 112(1):27-32

28. Oszmiański J, Wojdyło A, Lachowicz S, Gorzelany J, Matłok N (2016) J Func Foods 22:232-242

29. Côté J, Caillet S, Doyon G, Sylvain JF, Lacroix M (2010) Crit Rev Food Sci Nutr 50(9):872-888

30. Iswaldi I, Gómez-Caravaca AM, Arráez-Román D, Uberos J, Lardón M, Segura-Carretero A, Fernández-Gutiérrez A (2012) J Pharmaceut Biomed 58:34-41

31. Wu X, Prior RL (2005) J Agric Food Chem 53(7):2589-2599

32. White BL, Howard LR, Prior RL (2009) J Agric Food Chem 58(7):4030-4036

33. Lachowicz S, Kolniak-Ostek J, Oszmiański J, Wiśniewski R (2017) J Food Process Pres 41(1):1-10

34. Macheix JJ, Fleuriet A (1990) Fruit phenolics. CRC Press, US, pp 1-39

35. Dragovic-Uzelac V, Pospišil J, Levaj B, Delonga K (2005) Food Chem 91(2):373-383

36. Kondo M (2006) University of Massachusetts Dartmouth: North Dartmouth, pp 71-97

37. Szakiel A, Pączkowsk C, Pensec F, Bertsch C (2012) Phytochem Rev 11(2-3):263-284

38. McKenna JK, Hughes K, Humphrey S (2002) The Haworth Herbal Press, Oxford

39. Namiesnik J, Vearasilp K, Kupska M, Ham KS, Kang SG, Park YK, Barasch D, Nemirovski A, Gorinstein S (2013) Eur Food Res Technol 237(5):819-829

40. Sreelatha S, Padma PR (2009) Plant Food Hum Nutr 64(4):303 